OPEN ACCESS

Edited by:

Marzia Duse,

Università degli Studi di Roma La

Sapienza, Italy

Reviewed by:

Christoph Kessel,

Universitätsklinikum Münster

Germany

Markus Bender,

Universitätsklinikum Würzburg,

Germany

*Correspondence:

Ricardo A. G. Russo

rrusso@garrahan.gov.ar

Specialty section:

This article was submitted to

Pediatric Immunology,

a section of the journal

Frontiers in Pediatrics

Received: 14 June 2018 Accepted: 05 September 2018

Published: 24 September 2018

Citation:

Russo RAG and Katsicas MM (2018)

Takayasu Arteritis.

Front. Pediatr. 6:265

doi: 10.3389/fped.2018.00265

\section{Takayasu Arteritis}

\author{
Ricardo A. G. Russo* and María M. Katsicas \\ Service of Immunology \& Rheumatology, Hospital de Pediatría "Prof. Dr. Juan P. Garrahan", Buenos Aires, Argentina
}

Takayasu arteritis is an idiopathic granulomatous vasculitis of the aorta and its main branches and it constitutes one of the more common vasculitides in children. Inflammation and intimal proliferation lead to wall thickening, stenotic or occlusive lesions, and thrombosis, while destruction of the elastica and muscularis layers originates aneurysms and dissection. Carotid artery tenderness, claudication, ocular disturbances, central nervous system abnormalities, and weakening of pulses are the most frequent clinical features. The diagnosis is usually confirmed by the observation of large vessel wall abnormalities: stenosis, aneurysms, occlusion, and evidence of increased collateral circulation in angiography, MRA or CTA imaging. The purpose of this revision is to address the current knowledge on pathogenesis, investigations, classification, outcome measures and management, and to emphasize the need for timely diagnosis, effective therapeutic intervention, and close monitoring of this severe condition.

Keywords: Takayasu, arteritis, vasculitis, aorta, large vessel, children

\section{INTRODUCTION}

Takayasu arteritis (TA) is an idiopathic, granulomatous, large-vessel arteritis that predominantly involves the aorta, its major branch arteries, and (less frequently) the pulmonary arteries (1). The disease has been referred to with a number of different names in the past, such as aortic arch syndrome, pulseless disease, idiopathic aortitis, stenosing aortitis, aortoarteritis, and occlusive thromboarteriopathy. The Chapel Hill Consensus Conference defined TA as "a granulomatous inflammation of the aorta and its branches 'usually' occurring in patients younger than 50 years" (2). The disease is named after Mikito Takayasu, a Japanese ophthalmologist, who first described the arterio-venous anomalies in the retina of a patient with the disease in 1908. Inflammation and endothelial damage usually lead to wall thickening, thrombus formation, stenotic and occlusive lesions, while destruction of the muscularis and elastic layers originates dilatation and aneurysms. These lesions often result in organ dysfunction secondary to ischemia (3). It is the most common cause of granulomatous inflammation of large arteries and the third most common cause of vasculitis in the pediatric age group (4). Paucity of specific symptoms and laboratory biomarkers, as well as difficulties in assessing disease activity and progression, make the disease often unrecognized at onset, and its activity frequently underestimated. The disease course is commonly persistently active, allowing silent damage accrual and significant short- and longterm morbidity and mortality. However, early diagnosis and integrative management principles have led to better survival rates. 


\section{EPIDEMIOLOGY}

TA has been recognized worldwide. Its overall incidence has been estimated to be $2 / 1,000,000$ per year $(1,5)$. It is more prevalent in Central and South America, Africa, India, and the Far East (6-8). In Israel, TA has been reported in Sephardic but not in Ashkenazi Jews (9). It occurs more frequently in women, who represent up to $90 \%$ of cases in adults, while series on childhood TA have shown different female/male ratios: 6.9:1 in Mexico (10), 4.3:1 in Korea (11), 3.2:1 in the USA (12), 2.8:1 in Turkey (13), 1.9:1 in India (14), 1.7:1 in South Africa (15), and 1.2:1 in Israel (16). Although age of onset ranges from infancy to middle age, the highest incidence occurs during the third decade of life $(1,12,17-22)$. Some authors have found a double peakincidence: one at age 10-15 years and a second one at age 2024 years. Female patients seem to have a major incidence peak between age 15 and 19 years $(23,24)$. TA is rare but it is the commonest large vessel vasculitis in children, representing the leading cause of stenotic aorto-arteriopathy and one of the most prevalent causes of reno-vascular hypertension in childhood (24, 25). Childhood TA is associated with mortality rates as high as $35 \%(12,14,26,27)$.

\section{PATHOGENESIS}

The etiology of Takayasu arteritis remains poorly understood, but genetic contribution to the disease pathogenesis is supported mainly by its association with the HLA complex. HLA associations are varied and different according to the patients' ethnic background. The strongest association has been established with HLA-B52 in Japanese and other populations (28-30). HLA-B52 positive Japanese patients seem to carry a worse prognosis (31). Additionally, associations with HLA-B5 have been described in patients with Asian and Mexican Mestizo background, HLA-A2, -A9, and -B35 in Arabs and associations with HLA-DR4 have been found in North American patients, although replication studies have shown contradictory results (32-38). Certain polymorphisms (rs12524487 and rs9366782) in HLA-B/MICA have been associated with TA or risk of ischemic brain disease in TA in a Chinese population (39). A study in Indian patients found that the G allele at TNF- $\alpha-308$ was more common in TA patients than in controls, while the A allele was relatively less common in their study subjects than in Western individuals with the disease (40). A large genome-wide association study involving 449 patients with Northern European and Turkish ethnic backgrounds revealed two independent genetic susceptibility loci in the HLA class I and class II regions (HLA-B/MICA and HLA-DQB1/HLA$D R B 1$ ) and a genetic association with other loci, including FCGR2A/FCGR3A and IL12B (41). A study on Chinese patients found similar associations (42), while Terao et al. reported polymorphisms nearby $I L 12 B$ and $H L A-B$ (43). Additionally, a variant in $I L 17 F$ gene (rs763780) has been found to be protective against the development of TA (44).

A pathogenic role for infection has been hypothesized by several investigators, but supporting evidence has so far remained elusive or inconclusive. TA has been reported in HIV patients (45). Watanabe et al. (46) reported on a patient who developed a transient arteritis of both carotid arteries after influenza vaccination. A case of post-hepatitis B vaccination has been described (47). Similarly, the role of tuberculosis (TB) in TA is still controversial. Several published case-series have shown a variable proportion of TA patients who had evidence of preceding or concomitant infection with Mycobacterium tuberculosis (17, $27,48)$. In a Brazilian study of 71 children with TA, 23 patients (32\%) received anti-TB drugs for suspected or diagnosed TB (21). In a short series of Chinese TA patients, 4 out of 9 children had TB before the onset of symptoms (22). A case-control study from Mexico reported the presence of the IS6110 and HupBgene sequences associated with M. tuberculosis within the aortic tissue of TA patients. The authors speculated about the pathogenetic role of TB in the development of arteritis (49). Molecular mimicry between the mycobacterial $65-\mathrm{kDa}$ heatshock protein (HSP) and human 65-kDa HSP has been suggested, which could elicit an immunologically-mediated cross-reaction and lead to an autoimmune response (50). Several authors have reported the presence of $\mathrm{T}$ cells reactive to mycobacterial 65 $\mathrm{kDa}$ HSP and its homologous human HSP, as well as serum IgG antibodies directed toward mycobacterial and human 65$\mathrm{kDa}$ HSP, in patients with TA. Furthermore, the $65-\mathrm{kDa}$ HSP has been isolated from the middle layer and vasa vasorum in aortic biopsies from patients with TA $(50,51)$. Chauhan et al. (52) demonstrated circulating anti-aortic endothelial cell antibodies (AAECAs) that were directed against 60-65 kDa HSP in patients with TA. In this study, sera from AAECA-positive TA patients induced expression of adhesion molecules and secretion of proinflammatory cytokines by aortic endothelial cells, which suggests a potential pathogenic role of these autoantibodies. Finally, the association between TB and TA seems to be much weaker in countries with a low prevalence of TB (53).

Different immunological mechanisms are likely involved in TA pathogenesis (Figure 1). Both cell-mediated and humoral immune mechanisms lead to inflammation and tissue damage in TA (54). Both circulating anti-endothelial cell antibodies (AECA) and autoantibody-producing B cell infiltrates in inflamed vessels point to a role of humoral immunity $(52,55,56)$. The question of these mechanisms as being pathogenetic or an epiphenomenon remains open. Complement and cell mediated cytotoxicity by AECA have been demonstrated in patients with active disease (57) but these findings have not been replicated so far. Additionally, Hoyer et al. found a significant increase of newly generated plasmablasts in patients with active disease, suggesting a prominent role for $\mathrm{B}$ cells in the disease pathogenesis and supporting the use of anti-B cell therapies in TA (58). CD8positive $\mathrm{T}$ cells, the main components of the inflammatory infiltrates in affected vessels, have been proposed as key mediators of vessel damage through the release of perforin and granzymeB (55). Circulating and tissue-infiltrating $\gamma \delta$ T-cells have been reported to be expanded in TA patients during the active phases of the disease $(59,60)$. It is proposed that dendritic cells, activated by a stimulus so far unrecognized, recruit $T$ cells to the vessel wall. Different cytokines such as interferon (IFN) $-\gamma$ and tumor necrosis factor (TNF)- $\alpha$, allow the formation of granuloma. Simultaneously, perforin secreted by cytotoxic Tcells, $\gamma \delta \mathrm{T}$ cells, and natural killer (NK) cells, may contribute to the cell damage and necrosis in the medial and intimate layers. (61-63). 
Proinflammatory cytokines likely play an important role in the pathogenesis (64). Serum levels of IFN- $\alpha$, TNF- $\alpha$, interleukin6 (IL-6), IL-8, IL-17A, and IL-18 are increased in patients with TA (65-69). In particular, serum levels of IL-6, IL-12, and IL-18 correlate with disease activity, while high expression of IL- 6 in aortic tissue from TA patients has been reported. $(66,70,71)$. Misra et al. showed a significant expansion of Th17 cells and elevated serum IL-17 and IL-23 levels in TA patients as compared to healthy controls (72).

\section{CLINICAL MANIFESTATIONS}

The clinical manifestations of TA are different according to the time point along the disease course. During the early, actively inflammatory phase, non-specific systemic symptoms predominate for weeks or months, but they are frequently overlooked or considered to be indicative of more common, acute illnesses. During this stage, the disease course may follow a remitting/relapsing fashion, making diagnosis difficult $(14,27)$. Recurrent disease often occurs in new arterial territories, with the consequent coexistence of active and inactive (sequelae) lesions. The late, chronic phase (the "pulseless" stage) is characterized by ischaemia and symptoms secondary to arterial occlusion.

\section{General Manifestations}

Constitutional symptoms are observed in a higher proportion of childhood TA as compared to adult TA. General features are most frequent at onset of the disease and include hypertension in the majority of patients and, in decreasing order of frequency, the following: headaches (31\%), fever (29\%), dyspnoea (23\%), weight loss (22\%), vomiting (20\%), and musculoskeletal features (myalgia, arthralgia, or arthritis; $14 \%)(12,73)$. However, this non-specific symptoms are rarely disabling.

\section{Organ-Specific Manifestations Cardiovascular Features}

Cardiovascular features have been observed in $75-85 \%$ of pediatric patients, hypertension is present in over $80 \%$. Renal artery stenosis may lead to hyper-reninemic, renovascular hypertension, which may be asymptomatic in nearly $50 \%$ of patients (25). Systemic hypertension may be associated with a higher risk for arterial vessel wall dissection, a rare but lifethreatening complication which is less common in pediatric than in adult TA. Prevalence of dissection in childhood TA has been estimated at 11\% (74). Discrepancy of any of four limbs blood pressure $>10 \mathrm{~mm} \mathrm{Hg}$ (which constitutes a classification criteria item) as well as bruits over aorta and its major branches are present in over $50 \%$ of patients. Precordial pain, dyspnea, palpitations, and murmurs may reflect cardiac involvement. Dilated cardiomyopathy has been observed concomitantly with hypertension (14). Aortic valve insufficiency and congestive heart failure-an important cause of mortality-have been reported in a significant proportion of patients (73). Additionally, severe chest pain could be the presenting symptom of myocardial infarction-a very rare complication in children, occurring in $<5 \%$ cases-which can be confirmed on ECGs and/or elevated troponin (75). Pericarditis and valvular heart disease have been reported in a small percentage of patients. Lower-limb claudication due to ischemia is present in 10-35\% of childhood TA and may impact daily activities. Carotydinia (pain and tenderness on palpation over carotid bifurcation) is one of the most distinctive symptoms during the acute phases of the disease, but it is uncommon in childhood. Carotidynia may be aggravated by swallowing, coughing, sneezing, or turning the head to the contralateral side $(76,77)$.

\section{Cutaneous Features}

Cutaneous features have been observed in 2.8-28\% patients depending on series and race. Patients with cutaneous features seem to be most frequent in Japan (78). Skin involvement includes: livedo reticularis, purpura, erythema nodosum, subcutaneous edema, urticaria, digital gangrena, and ulcers. In certain cases, ulcerations may resemble pyoderma gangrenosum $(79,80)$.

\section{Neurological Features}

Nearly $20 \%$ of patients evidence neurological involvement, which can be the presenting symptom at disease onset. The most common neurological symptoms are severe headaches; organic confusion, cognitive dysfunction, stroke, meningitis, encephalitis, and seizures (not related to hypertension) may also occur $(81,82)$. Children with TA exhibit more frequent and heterogeneous neurological features than adults. Intracranial aneurysms have been reported; the middle cerebral artery is the most frequent site of involvement $(19,83,84)$. Posterior reversible encephalopathy syndrome, a neuroradiologic condition associated with headache, seizure, visual disturbances, and focal neurological deficit, has been described in childhood TA, albeit rarely (85).

\section{Gastrointestinal Features}

Gastrointestinal involvement occurs in approximately $10 \%$ of childhood TA cases. Stenotic arterial segments can cause ischemic symptoms: most frequently, acute or chronic abdominal pain is usually secondary to mesenteric ischemia caused by vasospasm of the damaged intestinal vasculature, which determines reduced blood flow in the intestine during eating (11, 86). Abdominal pain can be associated with vomiting or nausea, blood in the stools, and diarrhea; occasionally, severe pain may reflect bowel perforation. Portal hypertension, an uncommon manifestation, has been reported (87).

\section{Ocular Features}

Visual symptoms can be either transient or persistent and progressive. The ocular manifestations in TA usually follow occlusion or severe stenosis of the carotid arteries, and they commonly appear late during the disease course. Signs of conjunctival and episcleral vascular dilation may occur, but retinal abnormalities are most prominent (88). Complications due to ischemia, vitreous hemorrhage, retinal detachment, or optic atrophy may lead to blindness (88). The most common retinal findings include tortuosity and dilation of retinal veins, arterio-venous shunts, and microaneurysm in the peripheral retina. Acute loss of vision, sometimes associated with orbital 


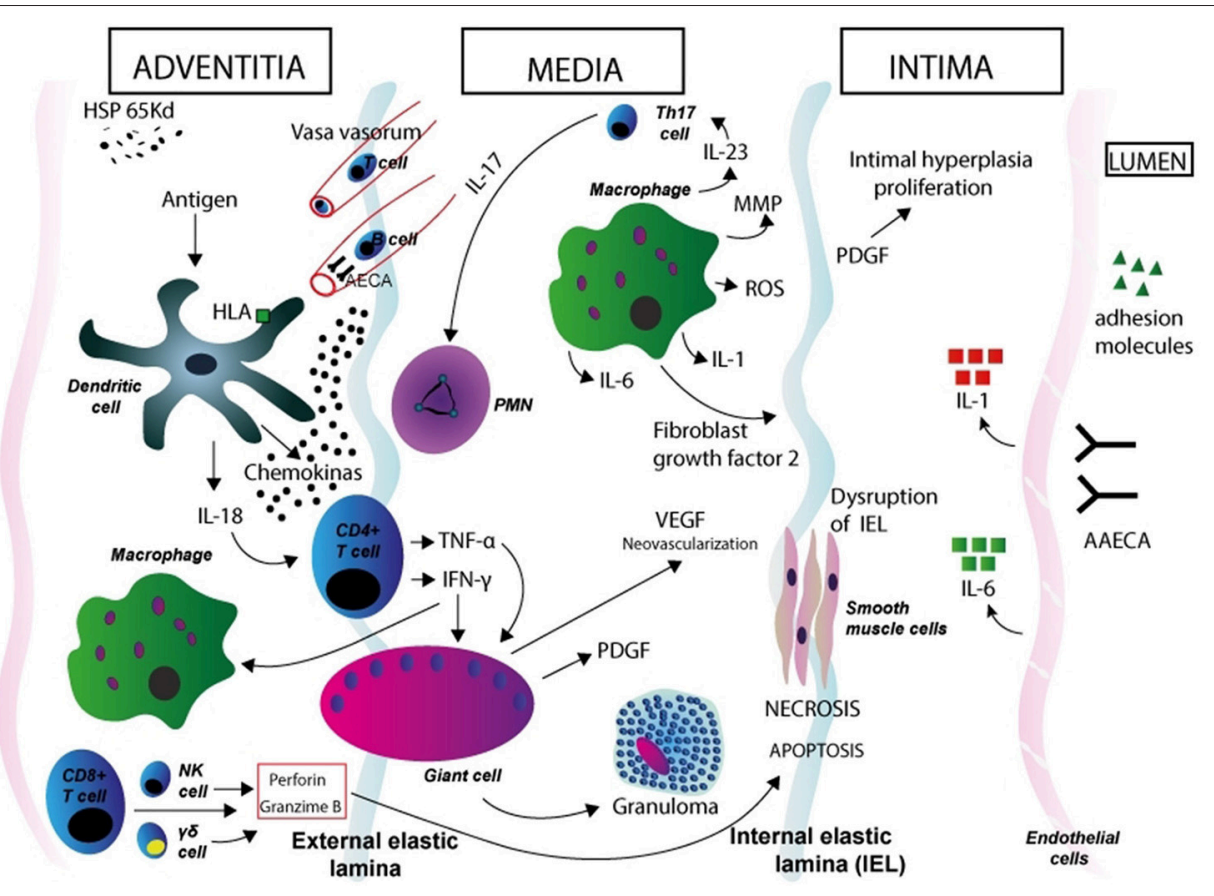

FIGURE 1 | Immunopathogenesis of Takayasu arteritis. Schematic figure showing possible mechanisms in the aortic wall. Dendritic cells in the adventitia expressing specific HLA molecules are activated by a stimulus so far unrecognized. Expression of the $65 \mathrm{kDa} \mathrm{HSP}$ in the aortic tissue might play a role in dendritic cell activation. These cells synthesize and release proinflammatory cytokines (such as IL-18) and homing chemokines that recruit T cells to the vessel wall and initiate an aberrant $T$ cell response. After interaction with dendritic cells, CD4-positive T cells with a Th1 phenotype release cytokines such as interferon (IFN)- $\gamma$ and tumor necrosis factor (TNF)- $\alpha$, which induce differentiation and increased function of macrophages, and also induce the coalescence of multinucleated giant cells, thus promoting the formation of granuloma. T cells with an induced Th17 phenotype release IL-17, which attracts and activates neutrophils in the vessel wall. Macrophages release IL-1 and IL-6, MMP, and ROS (which induce oxidative injury and degradation of media and intima layers, and disruption of the elastic laminae), VEGF (leading to neoangiogenesis), FGF, and PDGF, which results in exuberant intimal proliferation. These phenomena contribute to the structural damage in the aortic wall. IFN- $\gamma$, TNF- $\alpha$, IL-6, IL-8, IL-17A, and IL-18 likely play a role in vessel wall damage (through the recruitment of mononuclear cells in the vessel wall) and systemic features of TA. CD8-positive T cells, $\gamma \delta$ T-cells, and natural killer (NK) cells release of perforin and granzyme-B, which contribute to apoptosis and necrosis of smooth muscle cells and damage in the intimate layer. AAECA may also have a role in pathogenesis through the activation of endothelial cells and induction of complement- and cell-mediated cytotoxicity. Degenerative changes in the media and adventitia, as well as intimal fibrocellular hyperplasia, eventually lead to muscular layer weakening, aneurismal formation, vascular stenosis and thrombus formation. HSP, heat shock protein; HLA, human leukocyte antigen; PMN, polymorphonuclear neutrophil; NK, natural killer cell; MMP, matrix metalloproteinase; ROS, reactive oxygen species; PDGF, platelet-derived growth factor; VEGF, vascular endothelial growth factor; FGF, fibroblast growth factor; AAECA, anti-aortic endothelial cell antibodies.

pain, has been reported. Vision loss may be secondary to anterior uveitis, cystoid maculopathy, or ischemic optic neuropathy (89).

\section{Renal Features}

Features of renal involvement are rare, and include proteinuria, microscopic hematuria, and decreased glomerular filtration rate secondary to glomerulonephritis. Nephrotic syndrome and IgA nephropathy have been reported (90).

\section{Pulmonary Features}

Pulmonary involvement is uncommon. Pediatric TA patients may exhibit cough and dyspnea; pleural effusion, pulmonary infiltrates, alveolar hemorrhage, respiratory failure, and pulmonary hypertension have been reported in different case series $(25,27)$.

\section{Association Between Childhood TA and Other Rheumatic/Autoinmmune Diseases}

Different conditions have been reported in patients with TA. Coexistence of inflammatory bowel disease and TA in adult (and rarely in pediatric) patients has been described: almost 10\% patients with TA may develop Crohn's disease (CD) or CDlike colitis, indicating an association that exceeds the expected prevalence (91). Although the pathogenesis of both diseases remains unclear some similarities have been found, such as granulomatous vasculitis. Other reported associated diseases are pyoderma gangrenosum, ankylosing spondylitis, and juvenile idiopathic arthritis (92). Vettiyil et al. reported a patient who suffered from all TA, pyoderma gangrenosum, and chronic recurrent multifocal osteomyelitis (93).

\section{IMAGING}

Diagnosis and monitoring of TA require imaging of the blood vessels. Conventional angiography, contrast-enhanced magnetic resonance angiography (MRA), and Computed tomography angiography (CTA) offer advantages and disadvantages for the purpose (Table 1). Angiography using digital subtraction technique (DSA), the method used routinely for the evaluation 
of the arterial tree in patients with suspected or confirmed TA for decades, provides the best assessment of the vessel lumen (not the vessel wall), but it is invasive, it exposes the patient to ionized radiation and it is not devoid of complications risk (Figures 2, 3). For these reasons it is seldom used in clinical practice and non-invasive imaging methods have largely replaced it as a useful tool for diagnosis and follow up of TA patients. MRA has a comparable accuracy and sensitivity to DSA in the assessment of TA, particularly when lesions are in the aorta (Figure 4). It is non-invasive, it does not expose the patient to iodinated contrast load or radiation, and can provide information on arterial wall anatomy (thickness, edema, and contrast enhancement) during active, inflammatory phases on most vessels $(94,95)$. It is probably the most widely employed method for diagnosing and monitoring disease activity in patients with TA nowadays (it is certainly the technique of choice in the authors' experience) and it has been extensively used in children $(96,97)$. Diffusion-weighted MRI may be a useful imaging modality to assess the vascular inflammation and discriminate between active and non-active arterial lesions (98). Drawbacks of MRA include its inability to capture small vessels and the possibility of overestimating the degree of vascular stenosis (99). Typical features of childhood TA in angiography and MRA imaging are-similarly to findings in adult patientsstenosis, fusiform dilatations, aortic wall thickening, mural thrombi, and a bright signal in T2-weighted images indicating inflammatory edema of the vessel wall $(100,101)$. Stenotic lesions are usually found near the origin of the aortic branches; collateral vessels are indicative of the chronicity of stenotic lesions $(99,102$, 103). On the other hand, CTA has a better resolution-and it provides excellent anatomic detail in $3 \mathrm{D}$ reconstruction images (Figure 5) - , but exposes the patient to high radiation and it is not suit for repeat follow-up assessments. It is certainly helpful when MRA is not available. Both MRA and CTA provide crosssectional arterial wall images and allow detection of intramural inflammation, and they both demonstrate high specificity and sensitivity for the diagnosis and disease activity assessment (104-106).

Ultrasound (US) with color Doppler provides information about the morphology of the vessels and can also detect thrombosis and aneurysms, especially in the carotid arteries. It is inexpensive and does not use radiation or contrast, but it is operator-dependent and does not determine disease activity. A diffuse thickening of the intima-media complex, the "Macaroni sign," has been described in ultrasonographic studies of patients with TA (107). Recent studies have shown that US can provide important information about the vessel wall in pre-stenotic stages, when edema causes the vessel wall to appear hypoechoic, in contrast with its hyperechoic look in basal, non-inflammatory stages (108). US may, therefore, be a valuable method for follow up of TA patients. In the last few years, 18F-fluoro-deoxy-glucose (FDG) positron emission tomography (PET) imaging (18F-FDG-PET) has been added to the set of imaging procedures used in the evaluation of TA. This non-invasive method combines the measurement of metabolic activity of the arterial wall with lumenography, thus providing information about the degree of disease activity and anatomical abnormalities, even before morphologic changes appear on other imaging studies (109). According to some studies, the sensitivity and specificity of this method for clinical activity are close to $100 \%$ in TA patients, and it could detect subclinical activity (110-112). Other investigators, however, have found this method to be not as sensitive and specific for disease activity $(113,114)$. Besides, 18F-FDG-PET is expensive and exposes the patient to high doses of radiation if combined with CT (potentially avoided if MRA is substituted), which limits its use for follow up (115).

The 1994 International TA Conference in Tokyo established an angiographic classification on the basis of the distribution of the lesions $(116,117)$ : type I (branches of the aortic arch, classically associated with the typical pulseless disease), type IIa (ascending aorta, aortic arch and its branches), type IIb (ascending aorta, aortic arch and its branches, and thoracic descending aorta), type III (thoracic descending aorta, abdominal aorta, and/or renal arteries), type IV (abdominal aorta and/or renal arteries), and type $\mathrm{V}$ (combined features of types IIb and IV). Gubrandsson et al. proposed an additional category (prestenosis) for patients diagnosed before developing stenosis, based on the finding of abnormalities in the arterial wall or the aorta lumen on MRA, CTA, or PET (53). Ethnic and age-related differences in the pattern of arterial involvement have been reported. Type $\mathrm{V}$ and IV seem to be prevalent in children and non-Europeans $(12,21,22,27,53,118)$, while Type I may be the most common form in adults and Europeans (119). A large Japanese registry of 1,372 patients showed that the most common angiographic types were I and $\mathrm{V}$, being Type I prevalent in female patients, and type $\mathrm{V}$ in male patients. In this registry, patients with younger onset ( $<40$ years) had higher proportions of type I, IIa, and IIb, whereas patients with older onset had a higher proportion of type V and coronary artery lesions (23). A childhood TA series showed type I was the most common form of aortic involvement (13).

In a large Brazilian study involving 71 pediatric patients, imaging on 47 subjects demonstrated at baseline a change in abdominal aorta in $67.2 \%$ of patients, renal arteries in $55.2 \%$, and subclavian arteries and descending thoracic aorta in $26.9 \%$ each. Stenosis was present in $90 \%$, obstruction in $28.4 \%$ and aneurysm in $14.9 \%$. The most frequent angiographic type was type IV (21). In a Canadian study, the most frequently involved vessels were the abdominal aorta (89\%), the renal (67\%), and carotid arteries (56\%). Pulmonary arteries were involved in $19 \%$ of cases (48). Left subclavian and common carotid arteries appear to be more frequently involved than their contralateral pairs according to different series from different regions of the world (12, 53, 118, 120).

Finally, the European League Against Rheumatism (EULAR) has recently developed evidence-based recommendations for the use of imaging methods in large vessel vasculitis in clinical practice. MRA should be used as the first imaging test to make a diagnosis of TA and to investigate vessel wall inflammation and/or luminal changes, while PET, CT and/or US may be used as alternative imaging modalities (121). These recommendations 
TABLE 1 | Imaging modalities in the evaluation of Takayasu Arteritis patients.

\begin{tabular}{|c|c|c|}
\hline Modality & Advantages & Disadvantages \\
\hline Digital substraction angiography & $\begin{array}{l}\text { - Excellent morphological definition (lumen) } \\
\text { - Allows vision of distal vessels }\end{array}$ & $\begin{array}{l}\text { - Invasive } \\
\text { - Radiation } \\
\text { - Low sensitivity for assessment of disease activity } \\
\text { - Does not provide information about vessel wall }\end{array}$ \\
\hline Magnetic resonance angiography & $\begin{array}{l}\text { - Good morphological definition (lumen) } \\
\text { - Fairly good measurement of arterial wall thickness } \\
\text { - Allows vision of arterial wall edema } \\
\text { - Provides information on gadolinium uptake in vessel wall } \\
\text { - Good sensitivity for assessment of inflammation } \\
\text { - No radiation }\end{array}$ & $\begin{array}{l}\text { - Does not allows vision of small vessels } \\
\text { - It may overestimate stenosis } \\
\text { - Expensive }\end{array}$ \\
\hline Computed tomography angiography & $\begin{array}{l}\text { - Good morphological definition (lumen) } \\
\text { - Fairly good measurement of arterial wall thickness } \\
\text { - Good imaging of arterial lumen }\end{array}$ & $\begin{array}{l}\text { - Radiation } \\
\text { - Low sensitivity for assessment of disease activity } \\
\text { - Does not allow vision of small vessels }\end{array}$ \\
\hline Doppler ultrasound & $\begin{array}{l}\text { - Very good measurement of arterial wall thickness } \\
\text { - Provides fair definition of anatomical details } \\
\text { - Inexpensive } \\
\text { - Fair sensitivity for assessment of disease activity } \\
\text { - No radiation } \\
\text { - Non-invasive }\end{array}$ & $\begin{array}{l}\text { - Operator-dependant } \\
\text { - Poor definition of descending aorta } \\
\text { - No direct measure of inflammation }\end{array}$ \\
\hline $\begin{array}{l}\text { 18F-fluoro-deoxy-glucose positron emission } \\
\text { tomography }\end{array}$ & - Good sensitivity for early assessment of inflammation & $\begin{array}{l}\text { - Very poor definition of anatomic details } \\
\text { - Radiation } \\
\text { - Expensive } \\
\text { - It may underestimate activity }\end{array}$ \\
\hline
\end{tabular}

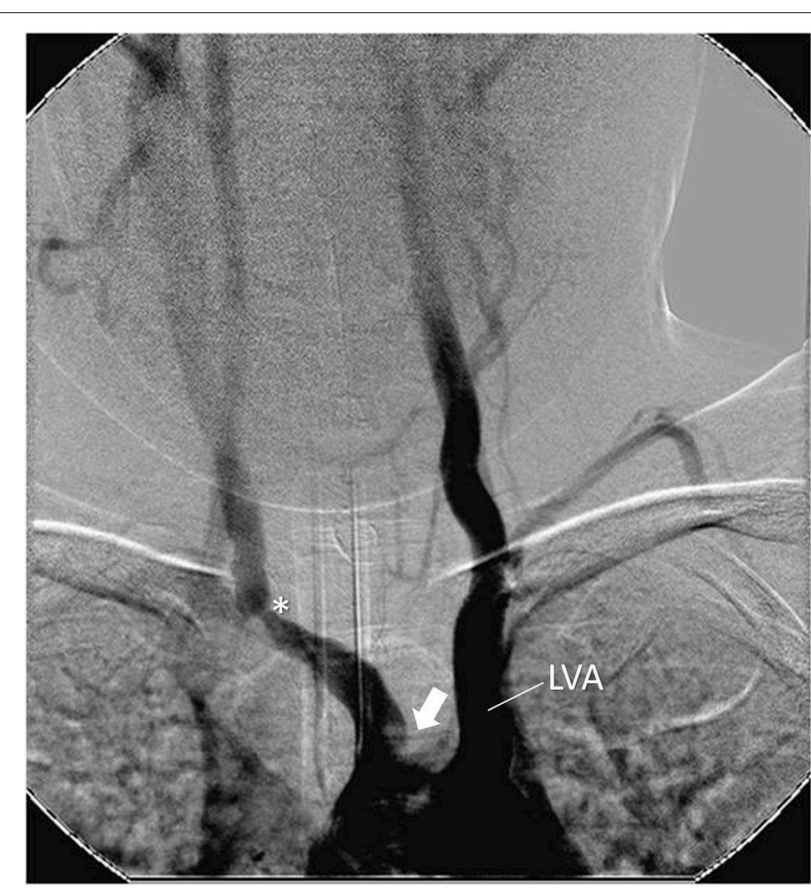

FIGURE 2 | Angiography showing stenosis in the brachiocephalic trunk at the subclavian emergence $\left(^{*}\right)$. Occlusion of left carotid artery close to the aortic arch (arrow). Left dilated vertebral artery emerging from the aortic arch (LV). Female, 7 year-old patient with Takayasu arteritis.

also propose MRA, CTA, and/or US as the imaging modalities to be used for long-term monitoring of disease activity and structural damage.

\section{PATHOLOGY}

Samples obtained during surgery or autopsy have provided evidence to the pathological findings in arteries of patients with TA (122). All layers of the arterial wall are affected. The initial site of inflammation is the medio-adventitial junction, where vasa vasora penetrate the artery wall. Active lesions usually exhibit edema, inflammatory infiltrates composed of mononuclear cells [dendritic cells, macrophages, NK cells, T cells $(\alpha \beta, \gamma \delta$, and cytotoxic $\mathrm{T}$ cells)], granulomatous reaction with giant cells, and necrosis in the media and adventitia, as well as intimal fibrocellular hyperplasia and thrombus formation, with ulterior degenerative changes leading to muscular layer weakening and aneurysmal formation. Chronic lesions are characterized by patchy infiltrates containing macrophages, media scarring and fibrosis, which extends to the adventitia. Changes may be diffuse or localized, and obstructive/stenotic lesions are more common than aneurysms in children $(123,124)$. Also, granulomata may be less common in pediatric patients (27).

\section{LABORATORY AND BIOMARKERS}

There are no specific laboratory tests for TA or available validated biomarkers of disease activity which could be useful for clinical care or clinical trials. Approximately one third of patients have no elevated inflammatory markers at presentation. Acute phase reactants, such as erythrocyte sedimentation rate (ESR) and C-reactive protein (CRP), are the most valuable non-imaging tests used to monitor disease course, although they correlate with disease activity only in a proportion of patients $(1,3$, $125,126)$. CRP levels, on the other hand, have been associated 


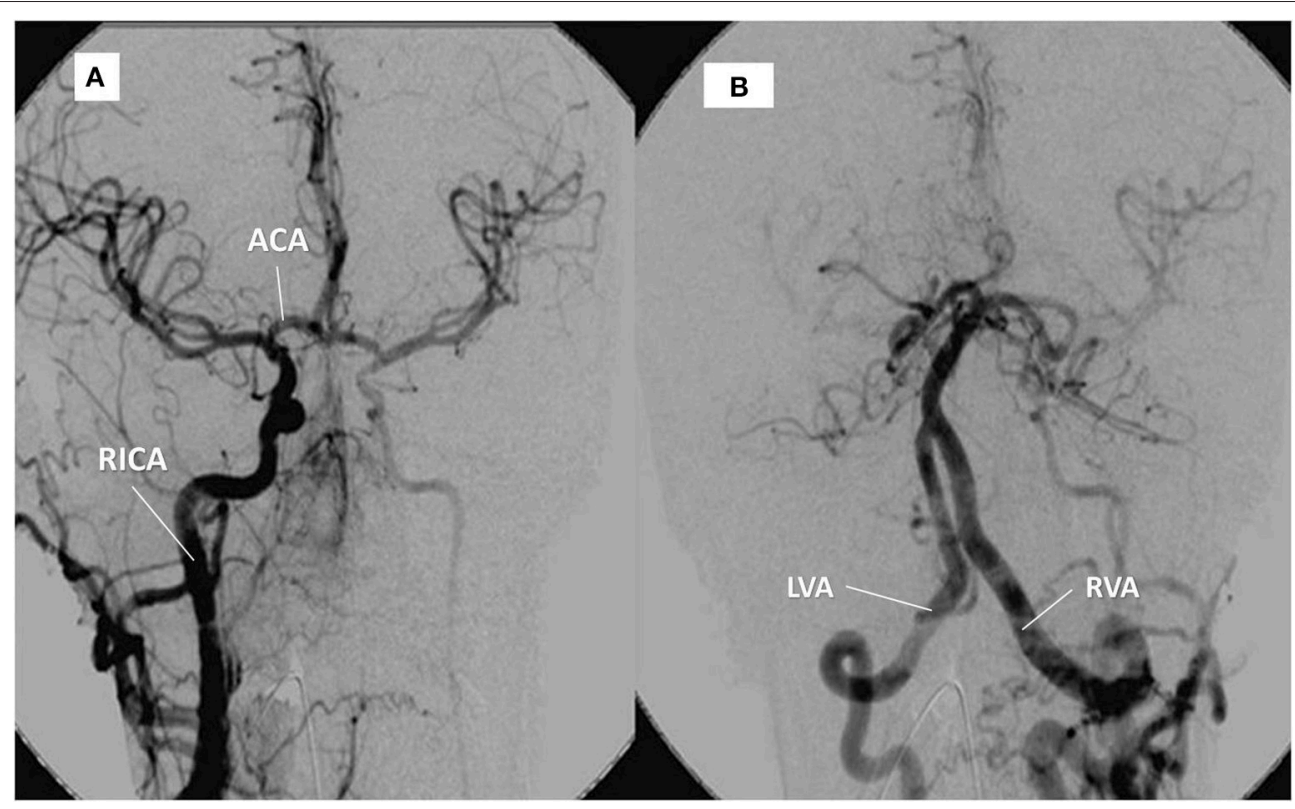

FIGURE 3 | Same patient as in Figure 1. (A) right internal carotid artery (RICA) supplying the left hemisphere through the anterior communicating artery (ACA). (B) contrast into the left, hypertrophic vertebral artery (LVA) provides supply to the right vertebral artery (RVA) and the territory of the (occluded) left carotid artery.
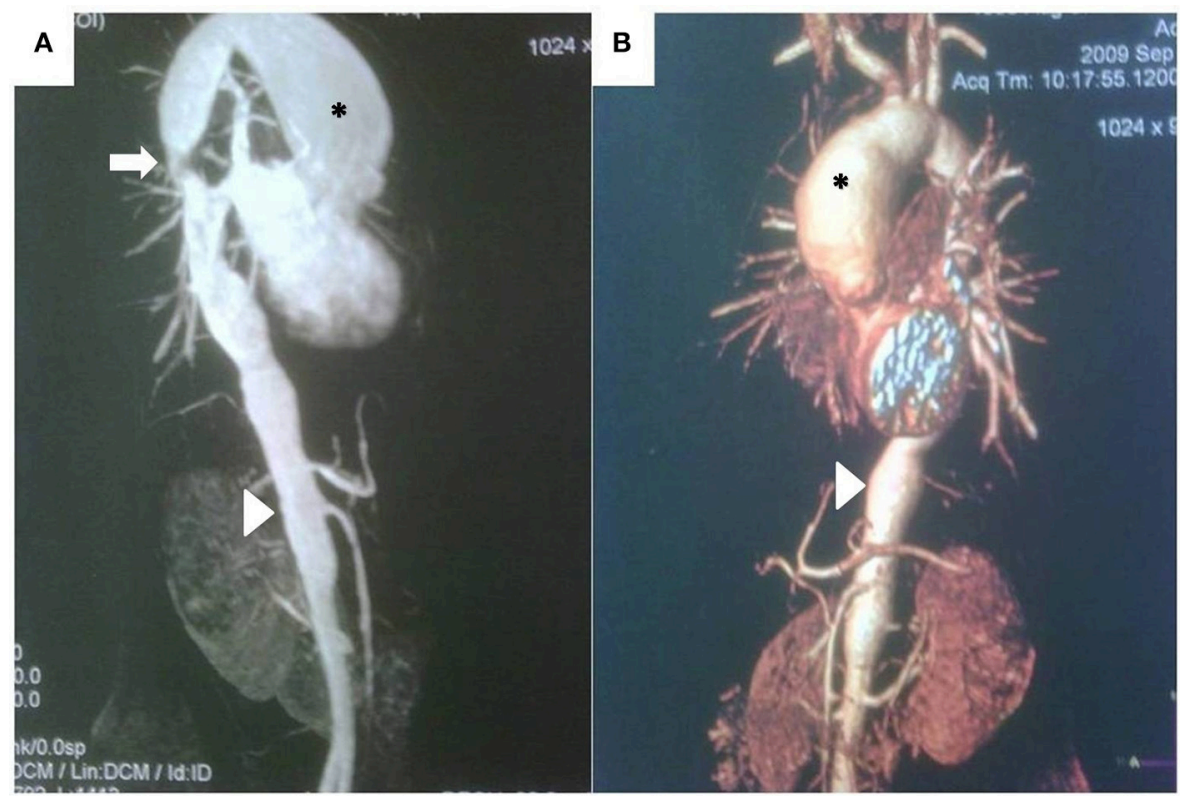

FIGURE 4 | (A) Magnetic resonance angiography demonstrating large, secular aneurysm in the aortic arch ( ${ }^{\star}$ ), stenosis in the thoracic aorta (arrow), and irregularity of the thoracic and abdominal aorta, including stenotic areas and a long aneurysm (arrowhead) proximal to the renal arteries in a 13 year-old girl with recent-onset Takayasu arteritis. (B) CT scan and three-dimensional reconstruction of the same patient, demonstrating same findings, but providing better quality-anatomical details.

with thrombotic events $(127,128)$. Normocytic, normochromic anemia, leukocytosis, thrombocytosis, and elevated serum amyloid A and fibrinogen may also accompany active phases of the disease. Serum autoantibodies such as AECA, circulating endothelial cells, and serum proteins such as Vascular Endothelial Growth Factor, matrix metalloproteinase-9, IL-6, and IL-18 have been investigated as potential biomarkers for disease activity in TA, but results have been so far inconclusive $(66,129-$ 131). Pentraxin3 (PTX-3) serum levels have been reported to be associated with active disease $(132,133)$. Also, plateletto-lymphocyte ratio (PLR) and neutrophil-to-lymphocyte ratio (NLR) have been reported to reflect the inflammatory phases 


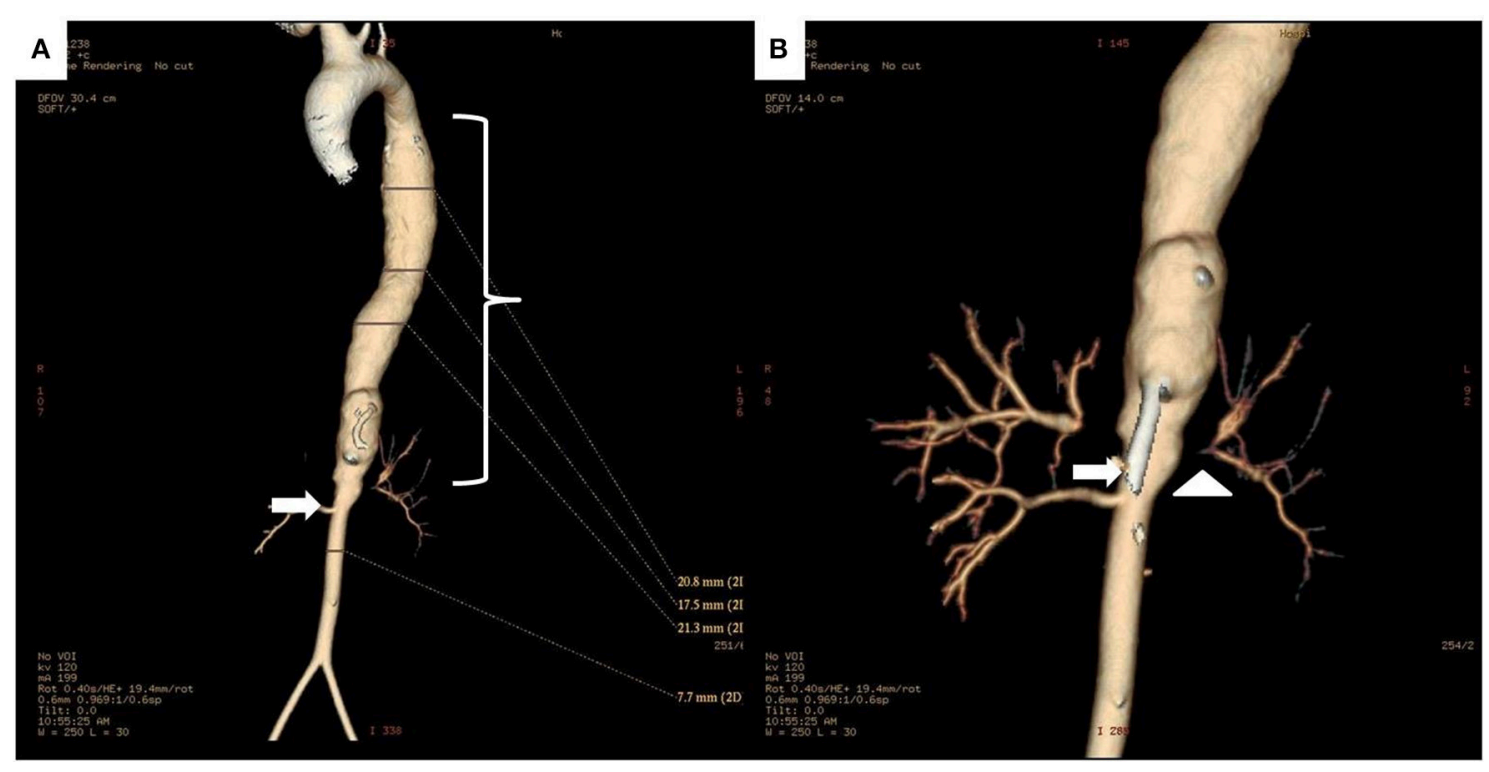

FIGURE 5 | (A) 3D reconstruction CT images of the whole aorta in a 12 year-old female Takayasu arteritis patient with thoraco-abdominal aortic aneurysm (bracket) proximal to a stenotic lesion (arrow) at the renal artery emergence site. (B) Detail of the aneurysmal dilatation and stenosis of the abdominal aorta (arrow), and stenosis of left renal artery (arrowhead).

of the disease (134). These findings still require confirmatory studies in clinical settings. Inflammation-induced thrombosis and platelet dysfunction may be common in TA. In a study, patients with TA had higher levels of platelet P-selectin and plasma thromboxane B2, and lower plasma cyclic adenosine monophosphate levels than healthy subjects, which indicated increased platelet activity (135). Akazawa et al. demonstrated that levels of $\beta$-thromboglobulin, thrombin/AT-III complex, fibrinopeptide $\mathrm{A}$, and $\mathrm{D}$-dimer are significantly higher in TA patients than in normal controls, reflecting a hypercoagulability state (136).

\section{DIAGNOSIS AND CLASSIFICATION CRITERIA}

The diagnosis of TA is challenging for the clinician. There are no specific laboratory abnormalities and the disease presentation is often non-specific, silent, or pauci symptomatic. Difficulty in recognizing the disease originates delay in diagnosis-which is close to 2 years median, and commonly several years long in pediatric TA-and consequently a worse prognosis. Approximately one third of children will be diagnosed in the stenotic, pulseless phase of the disease (12, $18,25-27,137)$. Suspicion is usually raised by the presence of hypertension, vascular bruits, asymmetric blood pressure between limbs or asymmetric arterial pulses in extremities, sometimes accompanied by fever, malaise or musculoskeletal symptoms. Even in the active phases of the disease, the laboratory may exhibit increased acute-phase proteins or be completely normal. The diagnosis of TA is based on the demonstration of lesions in the aorta or its major branches. Therefore, evaluation
TABLE 2 | Differential diagnosis in Takayasu arteritis.

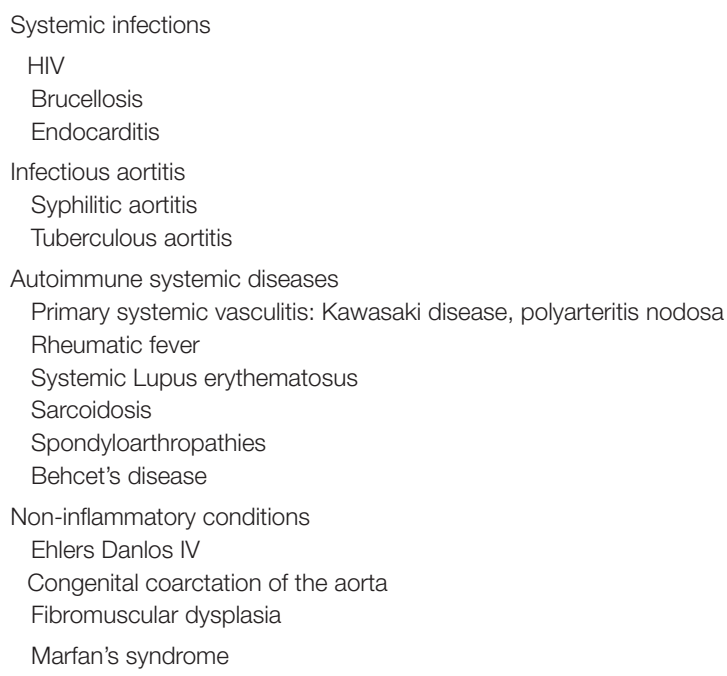

of the entire aorta and its main branches (including cranial vessels, irrespective of the presence of neurological symptoms) should be performed (138). Also, other causes of aortic and large vessel involvement should be excluded (Table 2). The differential diagnoses of TA include congenital disorders (such as aortic coarctation, Marfan syndrome, and fibromuscular dysplasia), other primary vasculitides, and secondary vasculitides [both infectious and autoimmune; (139)].

Different sets of diagnostic and classification criteria have been developed in adult patients to differentiate TA from other vasculitides. Their performance in pediatric patients is 
uncertain. The Ishikawa diagnostic criteria, developed in 96 Japanese TA patients, are based on 3 major and 10 minor criteria, and propose angiography as the main imaging modality to ascertain large vessel involvement $(18,140)$. The American College of Rheumatology (ACR) classification criteria were also developed to distinguish TA from other vasculitides in adults (141). There are no diagnostic criteria for TA in children. The EULAR/PRINTO/PRES criteria for the classification of childhood TA include angiographic abnormality (conventional, $\mathrm{CT}$, or MRI) of the aorta or its main branches and pulmonary arteries (mandatory criterion) plus at least one of the following: (1) absence of the peripheral artery pulse or claudication induced by physical activity; (2) $a>10 \mathrm{~mm} \mathrm{Hg}$ difference in systolic blood pressure in all four limbs; (3) bruits over large arteries; (4) hypertension (when compared with age-matched healthy children); and (5) increased levels of acute phase reactants (ESR and/or CRP). Fulfillment of these criteria provides a sensitivity and specificity over $99 \%$ (142).

\section{ASSESSING DISEASE ACTIVITY AND DAMAGE}

Lack of sensitive and specific biomarkers or "gold standard" imaging procedure poses a challenge to clinicians at the time of assessment of disease activity in TA. In practice, periodic examinations using non-invasive imaging methods (namely MRA), coupled with clinical manifestations and acute phase reactants, are commonly sufficient to monitor inflammatory activity and adjust therapy decisions accordingly. However, pathological studies have revealed arterial inflammatory activity in patients whose disease was clinically inactive $(1,13,143)$.

Different definitions of "activity," "remission/relapse," and scores to quantify disease activity and damage have been proposed by several authors (1, 144-152) (Table 3). One of the most commonly adopted approaches for disease activity assessment in TA is the definition by the US National Institute of Health (NIH) (1): active disease is defined as new onset or worsening of 2 or more from: (a) constitutional symptoms (fever, musculoskeletal pain with no other cause identified), (b) elevated ESR (>20 mm/h), (c) features of vascular ischemia or inflammation (such as claudication, diminished or absent pulse, bruit, vascular pain [carotydinia]), asymmetric blood pressure in either upper or lower limbs [or both]), and (d) new vascular lesions in previously unaffected vessels diagnosed by imaging examinations. Despite its widespread use in clinical settings, this definition has not been validated in pediatric patients yet.

The generic Birmingham Vasculitis Activity Score (BVAS) is a validated tool for small-vessel and medium-vessel vasculitis, but it has also been used as an outcome measure in TA by different investigators, both in adult and pediatric cohorts (144146). The components of BVAS include items indicative of disease activity in organ systems rarely affected in TA, while cardiovascular features (which predominate in TA) are underrepresented. Moreover, the absence of imaging data in this tool is a disadvantage in the assessment of disease activity in TA.
Overall, the BVAS score is generally considered a tool insufficient for appropriate measurement of activity in TA (147).

A disease-extent index for TA (DEI.Tak), which comprises 59 clinical (not imaging) items based on the BVAS components, was created for the follow-up of patients in 2005 (148). This score, which incorporates symptoms present in the previous 6 months, has been validated in adult TA patients (149). Also, a disease activity index based on items derived from BVAS and weighted for large-vessel vasculitis has been developed. Derived from DEI-Tak, the Indian Takayasu Clinical Activity Score (ITAS2010) (150) measures disease activity through the assessment of symptoms that occurred or worsened over the previous 4 weeks, and are persistent for $<3$ months. ITAS 2010 includes 44 items, with emphasis on cardiovascular symptoms (33 items). It has good comprehensiveness and the inter-rater agreement is better than a physician's global assessment (PGA). However, convergent validity by comparison to PGA is low. The ITAS-A score incorporates acute phase reactants to the ITAS2010. Both composite, TA-specific disease activity indices (ITAS2010 and ITAS-A) have been validated in adult TA patients, have demonstrated to be sensitive to change, and provide quantitative grading of disease activity (150). These instruments still need age-adaptation and validation in children.

The Pediatric Vasculitis Activity Score (PVAS), which was designed according to the BVAS layout, is the unique validated disease activity tool for children with primary vasculitis (151). However, it may not be optimal for assessment of disease activity in pediatric large vessel vasculitis,, despite patients with pediatric TA having been included in its development process.

Morbidity and mortality are associated with damage secondary to disease activity, therapies or comorbidities in TA. The Takayasu Damage Score (TADS) was derived from DEI.Tak to capture the extent of damage caused by the disease (147). It consists of 42 items in 7 fields, with an emphasis on the cardiovascular system, and records features which have present for at least 3 months. There are limitations in its use due to the difficult differentiation between activity and damage in large vessels. A vascular stenosis may be due to the inflammation taking place in an acute-phase, early state; however, it may also be a sign of an ongoing narrowing of the vessel wall in longstanding disease or the result of scarring. Further research is needed to test such discrimination of outcome tools. On the other hand, the Pediatric Vasculitis Damage Index (PVDI), a generic score developed for children based on the adult Vasculitis Damage Index (VDI), has been used in the assessment of childhood TA. It scores irreversible, cumulative disease-related damage and includes symptoms present for more than 3 months (152).

PVAS, ITAS2010, and PVDI have been used in pediatric TA, although they haven't been validated in this setting yet $(22,27,48)$. Specific and useful patient-reported outcomes, assessment of health-related quality of life, and probably additional composite measures for monitoring activity and damage still await development and validation in patients with childhood TA.

Finally, imaging-based scores have been developed. A disease activity score based on Doppler US has showed good correlation with clinical activity as measured by ITAS (153). Recently, a score 
TABLE 3 | Disease activity and damage scores used in childhood Takayasu Arteritis.

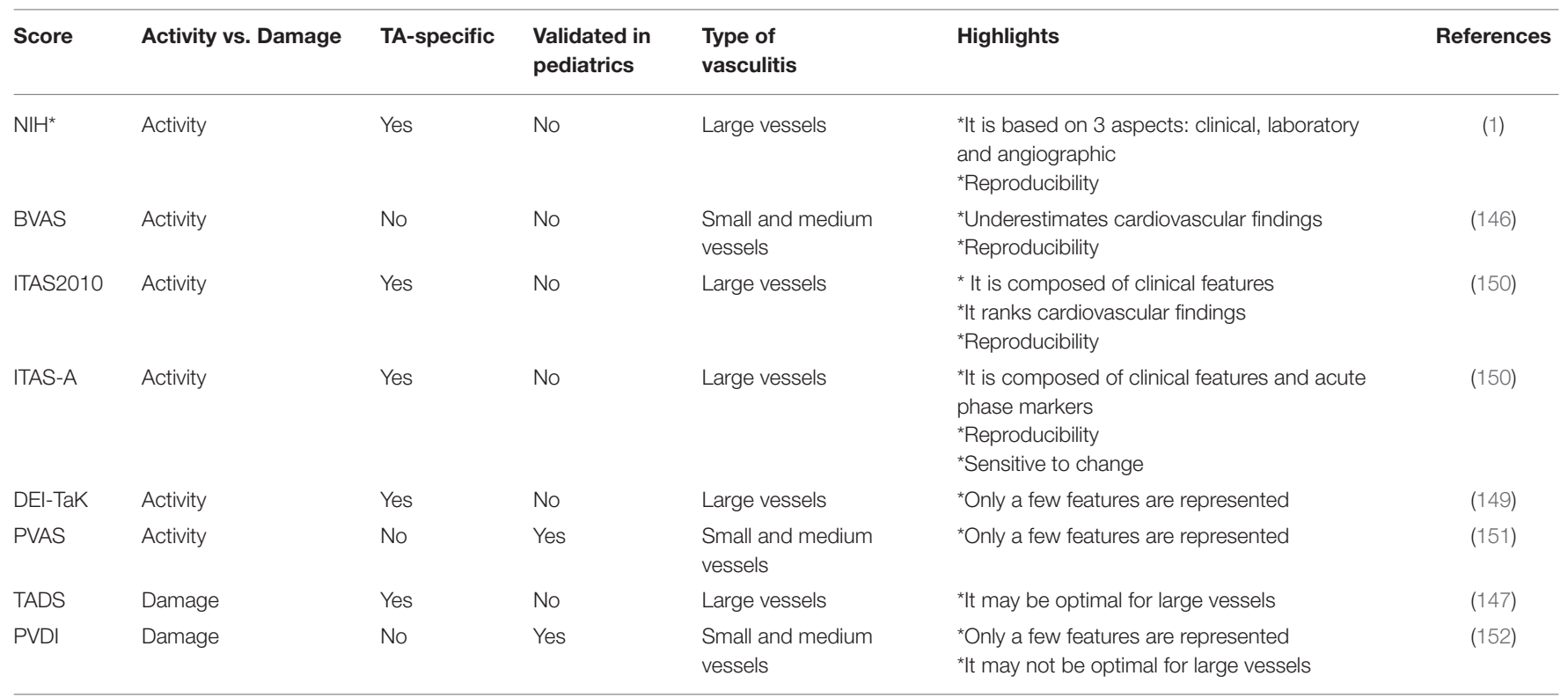

*Definition of activity. TA, Takayasu arteritis; NIH, National Institutes of Health; BVAS, Birmingham Vasculitis Activity Score; ITAS, Indian Takayasu Activity Score; DEI-TaK, Disease-Extent Index for Takayasu arteritis; PVAS, Pediatric Vasculitis Activity Score; TADS, Takayasu Damage Score; PVDI, Pediatric Vasculitis Damage Index.

for assessment of radiologic damage in adult TA patients was developed (154). It is based on the presence and extent of stenosis, occlusion, and aneurysms in large vessels (aorta and it branches and pulmonary arteries) as defined by imaging (MRA or CT).

\section{MANAGEMENT}

Treatment of TA is aimed at controlling vascular inflammation and preventing irreversible organ damage. Early diagnosis and timely, aggressive treatment are important in order to improve chances of a satisfactory outcome. After remission is achieved, treatment needs to be continued in the majority of patients to diminish risk of flares and disease progression. Inactive disease off medication is rare (48) and progression of vessel lesions may occur even during clinically inactive phases of the disease.

\section{Medical Treatment}

The EULAR 2009 recommendations for the management of large-vessel vasculitis propose early initiation of corticosteroid therapy for induction of remission, use of immunosuppressive agents as adjunctive therapy, and clinical monitoring of therapy with inflammatory markers as supportive data (155). Treatment recommendations for pediatric patients are lacking, but the results of the SHARE consensus recommendations will be available in the near future (156). General measures include blood pressure control: beta-adrenergic blockers, calcium channel blockers, diuretics or angiotensin converting enzyme (ACE) inhibitors have been used in children (27). ACE inhibitors should be used with caution in patients with renal artery stenosis, because their hyper-reninemic state predisposes them to a sudden drop in blood pressure which may pose risk to organs perfused by stenosed arteries.
There is limited data regarding efficacy of immunosuppressants (IS) in children with TA (Table 4). There have been no randomized therapeutic trials in pediatric patients and most available evidence has been derived from observational studies and from clinical trials performedin adult cohorts $(157,161)$. Classic IS (and biologic agents in the last decade) have been used in the induction and maintenance therapy of adult and pediatric patients with TA, but except for a few controlled clinical trials, most evidence arises from uncontrolled observations (27). Azathioprine, methotrexate (MTX), mycophenolate mofetil (MMF), leflunomide, and cyclophosphamide (CYC) are the most commonly used drugs used for induction or maintenance of remission in TA (162). During active phases, a combination of high-dose systemic corticosteroids (followed by progressive tapering) and IS is the mainstay of therapy, since corticosteroids alone fail to achieve or maintain remission in the majority of patients $(1,157)$. Maintenance therapy using IS is frequently necessary. Efficacy outcomes are diverse, and remission occurs in a significant proportion of patients treated with IS as demonstrated by different investigators $(157,163-165)$. In particular, clinical symptoms are improved while angiographic abnormalities do not regress but halt their progression $(166,167)$. Ozen et al. successfully and safely treated 6 patients with CYC and systemic corticosteroids for induction and MTX for maintenance of remission, and this has probably been the most widely used regime in pediatric TA so far (158). However, relapses are frequent on traditional IS.

The use of biological agents in the treatment of TA has gradually become widespread during the past 15 years. Except for two clinical trials, the evidence comes from case series that have shown the striking benefit of their use in adult 
TABLE 4 | Efficacy studies in Takayasu arteritis including pediatric patients.

\begin{tabular}{|c|c|c|c|c|c|c|}
\hline Agent & Dose & $\begin{array}{l}\text { Treatment } \\
\text { duration }\end{array}$ & Patients & Design & Outcome & Reference \\
\hline $\begin{array}{l}\text { Methotrexate + } \\
\text { corticosteroids }\end{array}$ & 10-25 mg/week & 34 months* & $\begin{array}{l}18 \text { patients } \\
\text { (children included) }\end{array}$ & $\begin{array}{l}\text { Open label, } \\
\text { prospective }\end{array}$ & Remission 81\% & $(157)$ \\
\hline $\begin{array}{l}\text { CYC followed by } \\
\text { MTX + } \\
\text { corticosteroids }\end{array}$ & $\begin{array}{l}\text { CYC 1.5-1.7 } \\
\mathrm{mg} / \mathrm{kg} / \text { day, MTX } \\
12.5 \mathrm{mg} / \mathrm{m} 2 / \text { week }\end{array}$ & $\begin{array}{l}12 \text { weeks followed } \\
\text { by } 12-18 \text { months } \\
\text { maintenance }\end{array}$ & 6 children & $\begin{array}{l}\text { Open label, } \\
\text { retrospective }\end{array}$ & Remission 100\% & $(158)$ \\
\hline Tocilizumab & $\begin{array}{l}8 \text { mg/kg every } 4 \\
\text { weeks }\end{array}$ & 9.5 months ${ }^{\star}$ & 4 children & $\begin{array}{l}\text { Open label, } \\
\text { retrospective }\end{array}$ & Remission $100 \%$ & (159) \\
\hline Tocilizumab & 162 mg SQ & 12 months & $\begin{array}{l}30 \text { adults, } 6 \\
\text { children }\end{array}$ & RDBPC & $\begin{array}{l}\text { Relapse in } 44 \% \text { TCZ, } \\
61 \% \text { placebo }\end{array}$ & $(160)$ \\
\hline
\end{tabular}

CYC, cyclophosphamide; MTX, methotrexate; TCZ, tocilizumab; RDBPC, randomized, double-blind, placebo-controlled. *Median.

and childhood TA. TNF-inhibitors (TNFi; etanercept, and particularly the anti-TNF- $\alpha$ monoclonal antibodies, adalimumab, and infliximab), the IL-6 inhibitor, tocilizumab (TCZ), and B-cell-directed strategies such as the monoclonal anti-CD20 antibody rituximab have been increasingly used in the treatment of TA in children. Anecdotal reports have shown reduction in disease activity or even remission in most pediatric and adult patients who are refractory to other therapies or steroidresistant/dependent $(58,159,168-174)$. Additionally, the flarefree survival time is longer in patients on biologics than in patients on traditional IS (175). In particular, TCZ seems to be effective even when traditional IS and TNFi have failed, according to different case- and small series-reports (70, 159, 172, 176-182). In a small, randomized, controlled trial using subcutaneous TCZ in 36 TA patients (6 of them were children) the primary endpoint (reduction in time to flare) could not be met, but the relapse-free rate showed a trend in favor of treated patients (160). Finally, a recent multicenter, controlled trial involving 34 patients with TA failed to demonstrate the efficacy of abatacept (CTLA4Ig) in maintaining relapse-free survival over placebo. (183). Additionally, since patients with TA may have a hypercoagulable state, some authors advocate the use of heparin or anti-platelet therapy in order to lower the incidence of ischemic events (136, 184).

\section{Surgical Treatment}

Vascular surgery has a relevant adjunctive role in the management of patients with TA; it can reduce mortality and improve the long-term prognosis. According to different series, at least one third of children with TA will require surgical interventions $(12,13,21,27,185)$. Irreversible stenotic or obstructive vascular lesions with hemodynamic impact require revascularization procedures, which should be performed during the quiescent phases of the disease and only in centers with expertise (155, 186-189). Indications for revascularization also include cerebrovascular disease due to cervicocranial vessel stenosis, coronary artery disease, severe coarctation of the aorta, aortic aneurysms, renovascular hypertension, end-organ ischemia, peripheral limb ischemia, and progressive aneurysm enlargement with risk of rupture or dissection (190).
Percutaneous transluminal angioplasty with balloon or stenting have long been used in TA, but despite providing short term benefit, re-stenosis, and aneurysmal formation are frequent and may occur within 1 or 2 years, and justify new interventions such as bypass surgery $(24,124,190-192)$. Percutaneous renal artery stenting has been useful in children with acute renal failure due to severe bilateral renal artery stenosis (193) and it is an effective therapy for the management of refractory renovascular hypertension; aorto-renal bypass and renal unilateral or bilateral autotransplantation are also recommended. (124, 194, 195). Moderate to severe aortic regurgitation, which may lead to cardiac congestive failure, requires early surgical correction, even in very young patients (196).

\section{OUTCOME}

Recent advances in early diagnosis and effective treatment options have significantly reduced mortality and morbidity in childhood TA, but disease course is still progressive, with repeated flares and the need for continuous IS therapy in over $80 \%$ cases $(1,12,14,27)$. Early identification of patients at risk for treatment failure and disease flare is still challenging. Children treated with biologic agents carry significantly better outcomes as compared to children treated with non-biologic therapies. Flarefree survival rates were higher for patients on TNFi or TCZ as compared to non-biologic IS ( 80 vs. $43 \%$ at 2 years, $p=$ 0.03) in the case-series by Aeschlimann et al. (48). Moreover, children receiving biologic therapies were more likely to achieve inactive disease at last follow-up than children treated with MTX, azathioprine, or MMF $(p=0.02)$. Damage accrual is frequent and usually reflects vessel stenosis: absent pulses (70\%), claudication of the extremities (33\%), cerebro-vascular accidents (26\%) and seizures $(11 \%)$ were relatively common during a 2.1 years follow up of childhood TA patients in that series.

Causes of death include complications such as arterial dissection, aortic rupture, uncontrollable hypertension, cardiomyopathy, myocardial infarction, renal failure, and infection $(15,21,27,48)$. Mortality rate ranges between 7 and $35 \%$ according to different series $(7,13,15,21,26,27)$. Extent of arterial and cardiac involvement, age of the patient, and severity of hypertension have a deep impact on prognosis $(13,25,26)$. In 
pooled adult and childhood TA series, fifteen-year survival rates varied according to the occurrence of arterial complications, valvular heart disease, stroke, heart failure, and renovascular hypertension: they were $66.3 \%$ in patients with and $96.4 \%$ for those without complications $(80,186,189,197)$.

\section{CONCLUSION}

Childhood TA is a rare but potentially life-threatening condition. Early diagnosis and timely, appropriate management are of utmost importance to reduce risk of morbidity and damage accrual. Hypertension, fever, unexplained weight loss, fatigue or arthralgia associated with vascular-related findings (such as bruits) may help raise the suspicion and prompt imaging investigations to reach an early diagnosis, which should be made before irreversible changes occur in the affected arteries. Assessment of extent of involvement and disease activity is mandatory for management of all patients. Classical inflammatory markers have limited utility in diagnosis and follow-up, and activity scores have not been validated in pediatric population yet. Non-invasive techniques (such as MRA) should be incorporated into the diagnosis and follow-up workup of patients. The level of evidence for the treatment of childhood

\section{REFERENCES}

1. Kerr GS, Hallahan CW, Giordano J, Leavitt RY, Fauci AS, Rottem $\mathrm{M}$, et al. Takayasu arteritis. Ann Intern Med. (1994) 120:919-29. doi: 10.7326/0003-4819-120-11-199406010-00004

2. Jennette JC, Falk RJ, Andrassy K, Bacon PA, Churg J, Gross WL, et al. Nomenclature of systemic vasculitides. Proposal of an international consensus conference. Arthritis Rheum. (1994) 37:187-92. doi: 10.1002/art.1780370206

3. Mason JC. Takayasu arteritis-advances in diagnosis and management. Nat Rev Rheumatol. (2010) 6:406-15. doi: 10.1038/nrrheum.2010.82

4. Zhu WH, Shen LG, Neubauer H. Clinical characteristics, interdisciplinary treatment and follow-up of 14 children with Takayasu arteritis. World J Pediatr. (2010) 6:342-7. doi: 10.1007/s12519-0100234-8

5. Reinhold-Keller E, Herlyn K, Wagner-Bastmeyer R, Gross WL. Stable incidence of primary systemic vasculitides over five years: results from the German vasculitis register. Arthritis Rheum. (2005) 53:93-9. doi: 10.1002/art.20928

6. Fries JF, Hunder GG, Bloch DA, McShane DJ, Arend WP, Calabrese LH, et al. The American College of Rheumatology 1990 criteria for the classification of vasculitis. Patients and methods. Arthritis Rheum. (1990) 33:1068-73.

7. Jain S, Sharma N, Singh S, Bali HK, Kumar L, Sharma BK. Takayasu arteritis in children and young Indians. Int J Cardiol. (2000) 75:S153-7. doi: 10.1016/S0167-5273(00)00180-7

8. Watts R, Al-Taiar A, Mooney J, Scott D, MacGregor A. The epidemiology of Takayasu arteritis in the UK. Rheumatology (2009) 48:1008-11. doi: 10.1093/rheumatology/kep153

9. Sekiguchi M, Suzuki J. An overview on Takayasu arteritis. Heart Vessels (1992) 7:6-10. doi: 10.1007/BF01744537

10. Soto ME, Espinola N, Flores-Suarez LF, Reyes PA. Takayasu arteritis: clinical features in 110 Mexican Mestizo patients and cardiovascular impact on survival and prognosis. Clin Exp Rheumatol. (2008) 26(3 Suppl. 49):S9-15.

11. Hong CY, Yun YS, Choi JY, Sul JH, Lee KS, Cha SH, et al. Takayasu arteritis in Korean children: clinical report of seventy cases. Heart Vessels Suppl. (1992) 7:91-6.
TA is low, and it is derived from open studies or case series. Conventional IS combined with corticosteroids are the mainstay of therapy, and in refractory cases, biologic agents (including TNFi and TCZ) should be considered as soon as possible in order to prevent end-organ damage due to ischemia. Revascularization of affected organs using endovascular (stenting or balloon) or bypass interventions are needed when arterial stenosis is severe. Improved awareness, timely diagnosis and incorporation of effective therapies and improved monitoring of the disease activity and response to therapy may result in better outcomes in the future.

\section{AUTHOR CONTRIBUTIONS}

All authors contributed conception and design of the review, wrote sections of the manuscript, contributed to manuscript revision, read and approved the submitted version.

\section{ACKNOWLEDGMENTS}

The authors would like to thank Dr. Carlos Rugilo (Service of Radiology, Garrahan Hospital) for his thoughtful and critical interpretation of images shown in this article.

12. Szugye HS, Zeft AS, Spalding SJ. Takayasu Arteritis in the pediatric population: a contemporary United States-based single center cohort. Pediatr Rheumatol Online J. (2014) 12:21. doi: 10.1186/1546-0096-12-21

13. Cakar N, Yalcinkaya F, Duzova A, Caliskan S, Sirin A, Oner A, et al. Takayasu arteritis in children. J Rheumatol. (2008) 35:913-9.

14. Goel R, Kumar TS, Danda D, Joseph G, Jeyaseelan V, Surin AK, et al. Childhood-onset Takayasu arteritis-experience from a tertiary care center in South India. J Rheumatol. (2014) 41:1183-9. doi: 10.3899/jrheum.131117

15. Hahn D, Thomson PD, Kala U, Beale PG, Levin SE. A review of Takayasu's arteritis in children in Gauteng, South Africa. Pediatr Nephrol. (1998) 12:668-75. doi: 10.1007/s004670050526

16. Rosenthal $\mathrm{T}$, Morag $\mathrm{B}$, Rubinstein Z, Itzchak Y. Takayasu arteritis in Israel-update. Int $J$ Cardiol. (1996) 54(Suppl.):S137-40. doi: 10.1016/S0167-5273(96)02812-4

17. Lupi-Herrera E, Sánchez-Torres G, Marcushamer J, Mispireta J, Horwitz S, Vela JE. Takayasu's arteritis. Clinical study of 107 cases. Am Heart J. (1977) 93:94-103. doi: 10.1016/S0002-8703(77)80178-6

18. Ishikawa K. Diagnostic approach and proposed criteria for the clinical diagnosis of Takayasu's arteriopathy. J Am Coll Cardiol. (1988) 12:964-72. doi: 10.1016/0735-1097(88)90462-7

19. Weiss PF, Corao DA, Pollock AN, Finkel TH, Smith SE. Takayasu arteritis presenting as cerebral aneurysms in an 18 month old: a case report. PediatrRheumatol Online J. (2008) 6:4. doi: 10.1186/1546-0096-6-4

20. Singh M, Hughes M, Sebire N, Brogan P. Takayasu arteritis in infancy. Rheumatology (2013) 52:2093-5. doi: 10.1093/rheumatology/ket109

21. Clemente G, Hilario MO, Lederman H, Silva CA, Sallum AM, Campos LM, et al. Takayasu arteritis in a Brazilian multicentre study: children with a longer diagnosis delay than adolescents. Clin Exp Rheumatol. (2014) 32(Suppl. 82):S128-33.

22. Feng Y, Tang X, Liu M, Zhou J, Zhao X, Li Q. Clinical study of children with Takayasu arteritis: a retrospective study from a single center in China. Pediatr Rheumatol Online J. (2017) 15:29. doi: 10.1186/s12969-017-0164-2

23. Watanabe Y, Miyata T, Tanemoto K. Current clinical features of new patients with Takayasu arteritis observed from CrossCountry Research in Japan. Circulation (2015) 132:1701-9. doi: 10.1161/CIRCULATIONAHA.114.012547 
24. Mathew AJ, Goel R, Kumar S, Danda D. Childhood-onset Takayasu arteritis: an update. Int J Rheum Dis. (2016) 19:116-26. doi: 10.1111/1756-185X.12718

25. Brunner J, Feldman BM, Tyrrell PN, Kuemmerle-Deschner JB, Zimmerhackl LB, Gassner I, et al. Takayasu arteritis in children and adolescents. Rheumatology (2010) 49:1806-14. doi: 10.1093/rheumatology/keq167

26. Morales E, Pineda C, Martínez-Lavin M. Takayasu's arteritis in children. J Rheumatol. (1991) 18:1081-4.

27. Eleftheriou D, Varnier G, Dolezalova P, McMahon AM, Al-Obaidi M, Brogan PA. Takayasu arteritis in childhood: retrospective experience from a tertiary referral centre in the United Kingdom. Arthritis Res Ther. (2015) 17:36. doi: 10.1186/s13075-015-0545-1

28. Yoshida M, Kimura A, Katsuragi K, Numano F, Sasazuki T. DNA typing of HLA-B gene in Takayasu's arteritis. Tissue Antigens (1993) 42:87-90. doi: 10.1111/j.1399-0039.1993.tb02172.x

29. Soto ME, Vargas-Alarcón G, Cicero-Sabido R, Ramírez E, Alvarez-León E, Reyes PA. Comparison distribution of HLA-B alleles in Mexican patients with Takayasu arteritis and tuberculosis. Hum Immunol. (2007) 68:449-53. doi: 10.1016/j.humimm.2007.01.004

30. Terao C, Yoshifuji H, Ohmura K, Murakami K, Kawabata D, Yurugi $\mathrm{K}$, et al. Association of Takayasu arteritis with HLA-B 67:01 and two amino acids in HLA-B protein. Rheumatology (2013) 52:1769-74. doi: 10.1093/rheumatology/ket241

31. Kasuya K, Hashimoto Y, Numano F. Left ventricular dysfunction and HLA Bw52 antigen in Takayasu arteritis. Heart Vessels Suppl. (1992) 7(Suppl.):116-9. doi: 10.1007/BF01744556

32. Hee-Park M, Bae-Park Y. HLA typing of Takayasu arteritis in Korea. Heart Vessels (1992) 7(Suppl.):81-4. doi: 10.1007/BF01744549

33. Mehra NK, Jaini R, Balamurugan AS, Kanga U, Prabhakaran D, Jain S, et al. Immunogenetic analysis of Takayasu arteritis in Indian patients. Int J Cardiol. (1998) 66(Suppl. 1):S127-32. doi: 10.1016/S0167-5273(98) 00160-0

34. Kharaishi MM, Gladman DD, Gagenais P, Fam AG, Keystone EC. HLA antigens in North American patients with Takayasu arteritis. Arthritis Rheum. (1992) 35:573-5. doi: 10.1002/art.1780350514

35. Vargas-Alarcón G, Zu-iga J, Gamboa R, Hernández-Pacheco G, Hesiquio $\mathrm{R}$, Cruz $\mathrm{D}$, et al. DNA sequencing of HLA-B alleles in Mexican patients with Takayasu arteritis. Int J Cardiol. (2000) 75:117-22. doi: 10.1016/S0167-5273(00)00188-1

36. Kimura A, Ota M, Katsuyama Y, Ohbuchi N, Takahashi M, Kobayashi Y, et al. Mapping of the HLA-linked genes controlling the susceptibility to Takayasu's arteritis. Int J Cardiol. (2000) 75(Suppl. 1):S105-10.

37. Salazar M, Varela A, Ramirez LA, Uribe O, Vasquez G, Egea E, et al. Association of HLA-DRB1*1602 and DRB1*1001 with Takayasu arteritis in Colombian mestizos as markers of Amerindian ancestry. Int J Cardiol. (2000) 75(Suppl. 1):S113-6. doi: 10.1016/S0167-5273(00)00181-9

38. Sahin Z, Bicakcigil M, Aksu K, Kamali S, Akar S, Onen F, et al. Takayasu's arteritis is associated with HLA-B* 52 , but not with HLA-B*51, in Turkey. Arthritis Res. (2012) 14:r27. doi: 10.1186/ar3730

39. Wen X, Chen S, Li J, Li Y, Li L, Wu Z, et al. Association between genetic variants in the human leukocyte antigen-B/MICA and Takayasu arteritis in Chinese Han population. Int J Rheum Dis. (2018) 21:271-7. doi: 10.1111/1756-185X.13012

40. Sandhya P, Danda S, Danda D, Lonarkar S, Luke SS, Sinha S, et al. Tumour necrosis factor (TNF)- $\alpha-308$ gene polymorphism in Indian patients with Takayasu's arteritis - A pilot study. Indian J Med Res. (2013) 137:749-52.

41. Saruhan-Direskeneli G, Hughes T, Aksu K, Keser G, Coit P, Aydin SZ, et al. Identification of multiple genetic susceptibility loci in Takayasu arteritis. Am J Hum Genet. (2013) 93:298-305. doi: 10.1016/j.ajhg.2013.05.026

42. Qin $F$, Wang $H$, Song $L$, Lu XL, Yang LR, Liang EP, et al. Single nucleotide polymorphism rs10919543 in FCGR2A/FCGR3A region confers susceptibility to takayasu arteritis in chinese population. Chin Med J. (2016) 129:854-9. doi: 10.4103/0366-6999.1 78965

43. Terao C, Yoshifuji H, Kimura A, Matsumura T, Ohmura K, Takahashi M, et al. Two susceptibility loci to Takayasu arteritis reveal a synergistic role of the IL12B and HLA-B regions in a Japanese population. Am J Hum Genet. (2013) 93:289-97. doi: 10.1016/j.ajhg.2013.05.024
44. Danda D, Goel R, Danda S, Mohan H, Joseph G, Kabeerdoss J, et al. Interleukin-17F and interleukin-6 gene polymorphisms in Asian Indian patients with Takayasu arteritis. Hum Immunol. (2017) 78:515-20. doi: 10.1016/j.humimm.2017.04.008

45. Shingadia D, Das L, Klein-Gitelman M, Chadwick E. Takayasu's Arteritis in a human immunodeficiency virus-infected adolescent. Clin Infect Dis. (1999) 29:458-9. doi: 10.1086/520244

46. Watanabe T. Transient Takayasu Arteritis after influenza vaccinations. Pediatr Infect Dis J. (2016) 35:596-7. doi: 10.1097/INF.0000000000001089

47. Castresana-Isla CJ, Herrera-Martinez G, Vega-Molina J. Erythema nodosum and Takayasu's arteritis after immunization with plasma derived hepatitis B vaccine. J Rheumatol. (1993) 20:1417-8.

48. Aeschlimann FA, Eng SWM, Sheikh S, Laxer RM, Hebert D, Noone D, et al. Childhood Takayasu arteritis: disease course and response to therapy. Arthritis Res Ther. (2017) 19:255. doi: 10.1186/s13075-017-1452-4

49. Soto ME, Avila-Casado MC, Huesca Gomez C, Alarcon GV, Castrejon V, Soto V, et al. Detection of IS6110 and HupB gene sequences of Mycobacterium tuberculosis and bovis in the aortic tissue of patients with Takayasu's arteritis. BMC Infect Dis. (2012) 12:194. doi: 10.1186/1471-2334-12-194

50. Kumar Chauhan S, Kumar Tripathy N, Sinha N, Singh M, Nityanand S. Cellular and humoral immune responses to mycobacterial heat shock protein-65 and its human homologue in Takayasu's arteritis. Clin Exp Immunol. (2004) 138:547-53. doi: 10.1111/j.1365-2249.2004.02644.x

51. Seko Y, Minota S, Kawasaki A, Shinkai Y, Maeda K, Yagita H, et al. Perforinsecreting killer cell infiltration and expression of a $65-\mathrm{kd}$ heat-shock protein in aortic tissue of patients with Takayasu's arteritis. J Clin Invest. (1994) 93:750-8. doi: 10.1172/JCI117029

52. Chauhan SK, Tripathy NK, Nityanand S. Antigenic targets and pathogenicity of antiaortic endothelial cell antibodies in Takayasu arteritis. Arthritis Rheum. (2006) 54:2326-33. doi: 10.1002/art.21921

53. Gubrandsson B, Molberg O, Garen T, Palm O. Prevalence, incidence, and disease characteristics of Takayasu Arteritis by ethnic background: data from a large, population-based Cohort Resident in Southern Norway. Arthritis Care Res. (2017) 69:278-85. doi: 10.1002/acr.22931

54. Arnaud L, Haroche J, Mathian A, Gorochov G, Amoura Z. Pathogenesis of Takayasu's arteritis: a 2011 update. Autoimmun Rev. (2011) 11:61-7. doi: 10.1016/j.autrev.2011.08.001

55. Inder SJ, Bobryshev YV, Cherian SM, Wang AY, Lord RS, Masuda $\mathrm{K}$, et al. Immunophenotypic analysis of the aortic wall in Takayasu's arteritis: involvement of lymphocytes, dendritic cells and granulocytes in immuno-inflammatory reactions. Cardiovasc Surg. (2000) 8:141-8. doi: 10.1016/S0967-2109(99)00100-3

56. Wang H, Ma J, Wu Q, Luo X, Chen Z, Kou L. Circulating B lymphocytes producing autoantibodies to endothelial cells play a role in the pathogenesis of Takayasu arteritis. J Vasc Surg. (2011) 53:174-80. doi: $10.1016 /$ j.jvs.2010.06.173

57. Tripathy NK, Upadhyaya S, Sinha N, Nityanand S. Complement and cell mediated cytotoxicity by Antiendothelial cell antibodies in Takayasu's Arteritis. J Rheumatol. (2001) 28:805-8.

58. Hoyer BF, Mumtaz IM, Loddenkemper K, Bruns A, Sengler C, Hermann KG, et al. Takayasu arteritis is characterized by disturbance of $\mathrm{B}$ cell homeostasis and responds to B cell depletion therapy with rituximab. Ann Rheum Dis. (2012) 71:75-9. doi: 10.1136/ard.2011.153007

59. Chauhan SK, Tripathy NK, Sinha N, Nityanand S. T-cell receptor repertoire of circulating gamma delta T-cells in Takayasu's arteritis. Clin Immunol. (2006) 118:243-9. doi: 10.1016/j.clim.2005.10.010

60. Tripathy NK, Gupta PC, Nityanand S. High TNF-a and low IL-2 producing T cells characterize active disease in Takayasu's arteritis. Clin Immunol. (2006) 118:154-8. doi: 10.1016/j.clim.2005.09.010

61. Inder SJ, Bobryshev YV, Cherian SM, Lord RS, Masuda K, Yutani C. Accumulation of lymphocytes, dendritic cells, and granulocytes in the aortic wall affected by Takayasu's disease. Angiology (2000) 51:565-79. doi: 10.1177/000331970005100705

62. Seko Y, Sugishita K, Sato O, Takagi A, Tada Y, Matsuo H, et al.: Expression of costimulatory molecules (4-1BBL and Fas) and major histocompatibility class I chain-related A (MICA) in aortic tissue with Takayasu's arteritis. J Vasc Res. (2004) 41:84-90. doi: 10.1159/000076437 
63. Weyand CM, Goronzy JJ: Medium and large vessel vasculitis. N Engl J Med. (2003) 349:160-9. doi: 10.1056/NEJMra022694

64. Noris M. Pathogenesis of Takayasu's arteritis. J Nephrol. (2001) 14:506-13.

65. Noris M, Daina E, Gamba S, Bonazzola S, Remuzzi G. Interleukin-6 and rantes in takayasu arteritis: a guide for therapeutic decisions? Circulation (1999) 100:55-60. doi: 10.1161/01.CIR.100.1.55

66. Park MC, Lee SW, Park YB, Lee SK. Serum cytokine profiles and their correlations with disease activity in Takayasu's arteritis. Rheumatology (2006) 45:545-8. doi: 10.1093/rheumatology/kei266

67. Alibaz-Oner F, Yentür SP, Saruhan, Park YB, Lee SK. -Direskeneli G, Direskeneli H. Serum cytokine profiles in Takayasu's arteritis: search for biomarkers. Clin Exp Rheumatol. (2015) 33(2 Suppl. 89):S-32-5.

68. Saadoun D, Garrido M, Comarmond C, Desbois AC, Domont F, Savey L. Th1 and Th17 cytokines drive inflammation in takayasu arteritis. Arthritis Rheumatol. (2015) 67:1353-60. doi: 10.1002/art.39037

69. Kong X, Sun Y, Ma L, Chen H, Wei L, Wu W. The critical role of IL6 in the pathogenesis of Takayasu arteritis. Clin Exp Rheumatol. (2016) 34(Suppl. 97):S21-7.

70. Abisror N, Mekinian A, Lavigne C, Vandenhende MA, Soussan M, Fain O. Tocilizumab in refractory Takayasu arteritis: a case series and updated literature review. Autoimmun Rev. (2013) 12:1143-9. doi: 10.1016/j.autrev.2013.06.019

71. Verma DK, Tripathy NK, Verma NS, Tiwari S. Interleukin 12 in Takayasu's arteritis: Plasma concentrations and relationship with disease activity. J Rheumatol. (2005) 32:2361-3.

72. Misra DP, Chaurasia S, Misra R. Increased Circulating Th17 Cells, Serum IL17A, and IL-23 in Takayasu Arteritis. Autoimmune Dis. (2016) 2016:7841718. doi: $10.1155 / 2016 / 7841718$

73. Kothari S. Takayasu's arteritis in children-a review. Images Paediatr Cardiol. (2001) 3:4-23.

74. Aeschlimann FA, Grosse-Wortmann L, Benseler SM, Laxer RM, Hebert D, Yeung RS. Arterial dissection in childhood Takayasu Arteritis: not as rare as thought. Pediatr Rheumatol. (2016) 14:56. doi: 10.1186/s12969-016-0115-3

75. Ishiyama Y, Eguchi K, Yokota K, Ikemoto T, Kario K. New-onset Takayasu's Arteritis as Acute Myocardial Infarction. Intern Med. (2018) 57:1415-20. doi: 10.2169/internalmedicine.9690-17

76. Zeina AR, Slobodin G, Barmeir E. Takayasu's arteritis as a cause of carotidynia: clinical and imaging features. Isr Med Assoc J. (2008) 10:158-9.

77. Schmidt WA, Seipelt E, Krause A, Wernicke D. Carotidynia in Takayasu arteritis. J Rheumatol. (2007) 34:231-2.

78. Dourmishev AL, Serafimova DK, Vassileva SG, Dourmishev LA, Schwartz RA. Segmental ulcerative vasculitis: a cutaneous manifestation of Takayasu's arteritis. Int Wound J. (2005) 2:340-5. doi: 10.1111/j.1742-4801.2005.00103.x

79. Chaffai M, Hanza M, Bnouni B, Ben Jilani S, Khalfat A. Pyoderma gangrenosum au cours d'une arterite de Takayasu. Ann Dermatol Venereol. (1982) 109:755.

80. Ishikawa K, Maetani S. Long-term outcome for 120 Japanese patients with Takayasu's disease. Clinical and statistical analyses of related prognostic factors. Circulation (1994) 90:1855-60. doi: 10.1161/01.CIR.90.4.1855

81. Brunner J, Armstrong D, Feldman BM, Schneider R, Benseler S. Childhood stroke as the presentation of Takayasu's arteritis: diagnostic delay can cause catastrophic complications. J Rheumatol. (2008) 35:1228-30.

82. Benjaminsen E, Reigstad A, Cengija V, Lilleby V, Carlsson M. Stroke as the sole manifestation of Takayasu Arteritis in a 15-year-old boy with latent tuberculosis. Case Rep Neurol Med. (2016) 2016:8736248. doi: $10.1155 / 2016 / 8736248$

83. Ringleb PA, Strittmatter EI, Loewer M, Hartmann M, Fiebach JB, Lichy C, et al. Cerebrovascular manifestations of Takayasu arteritis in Europe. Rheumatology (2005) 44:1012-5. doi: 10.1093/rheumatology/keh664

84. Klos K, Flemming KD, Petty GW, Luthra HS. Takayasu's arteritis with arteriographic evidence of intracranial vessel involvement. Neurology (2003) 60:1550-1. doi: 10.1212/01.WNL.0000058758.47170.AE

85. Lee KW, Lee ST, Cho H. Posterior reversible encephalopathy syndrome caused by presumed Takayasu arteritis. Korean J Pediatr. (2016) 59(Suppl. 1):S145-8. doi: 10.3345/kjp.2016.59.11.S145

86. Wu H, Virdi A. Chronic abdominal pain as a presentation symptom of Takayasu arteritis. Clin J Pain (2009) 25:349. doi: 10.1097/AJP.0b013e31818c490c
87. Herrera CN, Tomala-Haz JE. Portal hypertension: an uncommon clinical manifestation of Takayasu arteritis in a 9-year-old child. Open Access Rheumatol. (2016) 8:115-8. doi: 10.2147/OARRR.S114689

88. Chun YS, Park SJ, Park IK, Chung H, Lee J. The clinical and ocular manifestations of Takayasu arteritis. Retina (2001) 21:132-40. doi: 10.1097/00006982-200104000-00006

89. McDonald MA, Ojaimi E, Favilla I. Anterior uveitis in a child with Takayasu's arteritis. Clin Exp Ophthalmol. (2004)32:336-9. doi: $10.1111 / j .1442-9071.2004 .00828 . x$

90. van der Meulen J, Gupta RK, Peregrin JH, Al Adnani MS, Johny KV. Takayasu's arteritis and nephritic syndrome in a patient with crossed renal ectopia. Neth J Med. (1989) 34:142-7.

91. Reny JL, Paul JF, Lefèbvre C, Champion K, Emmerich J, Blétry O. Association of Takayasu's arteritis and Crohn's disease. Results of a study on 44 Takayasu patients and review of the literature. Ann Med Intern. (2003) 154: 85-90.

92. Taddio A, Maschio M, Martelossi S, Barbi E, Ventura A. Crohn's disease and Takayasu's arteritis: an uncommon association. World J Gastroenterol. (2013) 19: 5933-5. doi: 10.3748/wjg.v19.i35.5933

93. Vettiyil G, Punnen A, Kumar S. An Unusual Association of Chronic Recurrent Multifocal Osteomyelitis, Pyoderma Gangrenosum, and Takayasu Arteritis. J Rheumatol. (2017) 44:127-8. doi: 10.3899/jrheum.160491

94. Choe YH, Han BK, Koh EM, Kim DK, Do YS, Lee WR. Takayasu's arteritis: assessment of disease activity with contrast enhanced MRI imaging. Am J Roentgenol. (2000) 175:205-11. doi: 10.2214/ajr.175.2.1750505

95. Tso E, Flamm SD, White RD, Schvartzman PR, Mascha E, Hoffman GS. Takayasu arteritis: utility and limitations of magnetic resonance imaging in diagnosis and treatment. Arthritis Rheum. (2002) 46:1634-42. doi: 10.1002/art.10251

96. Aluquin VPR, Albano SA, Chan F, Sandborg C, Pitlick PT. Magnetic resonance imaging in the diagnosis and follow up of Takayasu's arteritis in children. Ann Rheum Dis. (2002) 61:526-9. doi: 10.1136/ard.61.6.526

97. Andrews J, Al-Nahhas A, Pennell DJ, Hossain MS, Davies KA, Haskard DO, et al. Non-invasive imaging in the diagnosis and management of Takayasu's arteritis. Ann Rheum Dis. (2004) 63:995-1000. doi: 10.1136/ard.2003. 015701

98. Kuroiwa Y, Tai H, Yamashita A, Furukoji E, Kihara Y, Hirai T, et al. High signal intensity in arterial walls on diffusion-weighted magnetic resonance imaging in the active phase of Takayasu Arteritis. Circ J. (2017) 81:174-8. doi: 10.1253/circj.CJ-17-0079

99. Sueyoshi E, Sakamoto I, Uetani M. MRI of Takayasu's arteritis: typical appearances and complications. Am J Roentgen (2006) 187:569-75. doi: 10.2214/AJR.05.1093

100. Yamada I, Numano F, Suzuki S. Takayasu arteritis: evaluating with MR imaging. Radiology (1993) 18:89-94. doi: 10.1148/radiology.188.1.8099751

101. McCulloch M, Andronikou S, Goddard E, Sinclair P, Lawrenson J, Mandelstam S, et al. Angiographic features of 26 children with Takayasu's arteritis. Pediatr Radiol. (2003) 33:230-5. doi: 10.1007/s00247-0020817-1

102. Matsunaga N, Hayashi K, Sakamoto I, Ogawa Y, Matsumoto T. Takayasu Arteritis: Protean Radiologic Manifestations and Diagnosis. Radiographics (1997) 17: 579-94. doi: 10.1148/radiographics.17.3.9153698

103. Kim ESH, Beckman J. Takayasu arteritis: challenges in diagnosis and management. Heart (2018) 104:558-65. doi: 10.1136/heartjnl-2016-310848

104. Yamada I, Nakagawa T, Himeno Y, Numano F, Shibuya H. Takayasu arteritis: evaluation of the thoracic aorta with CT angiography. Radiology (1998) 209:103-9. doi: 10.1148/radiology.209.1.9769819

105. Yamada I, Nakagawa T, Himeno Y, Kobayashi Y, Numano F, Shibuya H. Takayasu arteritis: diagnosiswith breath-hold contrast-enhanced threedimensional MR angiography. J Magn Reson Imaging (2000) 11:481-7. doi: 10.1002/(SICI)1522-2586(200005)11:5<481::AID-JMRI3>3.0.CO;2-4

106. Barta L, Kanji T, Malette J, Pagnoux C. Imaging modalities for the diagnosis and disease activity assessment of Takayasu's arteritis: a systematic review and meta-analysis. Autoimmune Rev. (2018) 17:175-87. doi: 10.1016/j.autrev.2017.11.021

107. Maeda H, Handa N, Matsumoto M. Carotid lesions detected by Bmode ultrasonography in Takayasu's arteritis: "macaroni sign" as an indicator of the disease. Ultrasound Med Biol. (1991) 17:695-701. doi: 10.1016/0301-5629(91)90101-2 
108. Schmidt W. Role of ultrasound in the understanding and management of vasculitis. Ther Adv Musculoskelet Dis. (2014) 6:39-47. doi: 10.1177/1759720X13512256

109. Horai Y, Kurushima S, Igawa T, Ichinose K1, Nakamura H1, Kawakami A. Coexistence of Takayasu's arteritis and inflammatory colitis detected by fluorodeoxyglucose positron emission tomography. Jpn J Clin Immunol. (2017) 40:387-90. doi: 10.2177/jsci.40.387

110. Meller J, Strutz F, Siefker U, Scheel A, Sahlmann CO, Lehmann K, et al. Early diagnosis and follow-up of aortitis with [18F]FDG PET and MRI. Eur J Nucl Med Mol Imaging (2003) 30:730-6. doi: 10.1007/s00259-003-1144-y

111. Webb M, Chambers A, Al-Nahhas A, Mason JC, Maudlin L, Rahman $\mathrm{L}$, et al. The role of $18 \mathrm{~F}-\mathrm{FDG}$ PET in characterizing disease activity in Takayasu arteritis. Eur J Nucl Med Mol Imaging (2004) 31:627-34. doi: 10.1007/s00259-003-1429-1

112. Karapolat I, Kalfa M, Keser G, Yalçin M, Inal V, Kumanlioglu K, et al. Comparison of 18F-FDG PET/CT findings with current clinical disease status in patients with Takayasu's arteritis. Clin Exp Rheumatol. (2013) 31(Suppl. 75):S15-21.

113. Arnaud L, Naroche J, Malek Z, Archambaud F, Gambotti L, Grimon G, et al. Is (18)F-fluorodeoxyglucose positron emission tomography scanning a reliable way to assess disease activity in Takayasu arteritis? Arthritis Rheum. (2009) 60:1193-200. doi: 10.1002/art.24416

114. Lee SG, Ryu JS, Kim N, Oh JS, Kim YG, Lee CK, et al. Evaluation of disease activity using F-18 FDG PET-CT in patients with Takayasu arteritis. Clin Nucl Med. (2009) 34:749-52. doi: 10.1097/RLU.0b013e3181b7db09

115. Tezuka D, Haraguchi G, Ishihara T, Ohigashi H, Inagaki H, Suzuki J, et al. Role of FDG-PET in Takayasu arteritis. JACC Cardiovasc Imaging (2012) 5:422-9. doi: 10.1016/j.jcmg.2012.01.013

116. Hata A, Noda M, Moriwaki R, Numano F. Angiographic findings of Takayasu arteritis: new classification. Int J Cardiol. (1996) 54(Suppl.):S15563. doi: 10.1016/S0167-5273(96)02813-6

117. Moriwaki R, Noda M, Yajima M, Sharma BK, Numano F. Clinical manifestations of Takayasu arteritis in India and Japan - new classification of angiographic findings. Angiology (1997) 48:369-79. doi: 10.1177/000331979704800501

118. Li J, Fen S, Chen Z, Yang Y, Zhao J, Li M, et al. The clinical characteristics of Chinese Takayasu's arteritis patients: a retrospective study of 411 patients over 24 years. Arthritis Res Ther. (2017) 19:107. doi 10.1186/s13075-017-1307

119. Setty HS, Rai M, Sinivas KH, Srinivas BC, Usha MK, Jayaranganath M, et al. Clinical, angiographic profile and percutaneous endovascular management of Takayasu's arteritis - A single centre experience. Int J Cardiol. (2016) 220:924-8. doi: 10.1016/j.ijcard.2016.06.194

120. Grayson PC, Maksimowicz-McKinnon K, Clark TM, Cuthbertson D, Carette S, Khalidi NA, et al. Distribution of arterial lesions in Takayasu's arteritis and giant cell arteritis. Ann Rheum Dis. (2012) 71:1329-34. doi: 10.1136/annrheumdis-2011-200795

121. Dejaco C, Ramiro S, Duftner C, Besson FL, Bley TA, Blockmans $\mathrm{D}$, et al. EULAR recommendations for the use of imaging in large vessel vasculitis in clinical practice. Ann Rheum Dis. (2018) 77:636-43. doi: 10.1136/annrheumdis-2017-212649

122. Walker M, Gallagher PJ. The surgical pathology of large vessel disease. Diagn Histopathol. (2009)16:10-6. doi: 10.1016/j.mpdhp.2009.09.007

123. Vaideeswar P, Deshpande JR. Pathology of Takayasu arteritis: a brief review. Ann Pediatr Cardiol. (2013) 6:52-8. doi: 10.4103/0974-2069.107235

124. D'Souza SJA, Tsai WS, Silver MM, Chait P, Benson LN, Silverman E, et al. Diagnosis and management of stenotic aorto-arteriopathy in childhood. J Pediatr. (1998) 132:1016-22. doi: 10.1016/S0022-3476(98)70401-9

125. Hoffman GS, Ahmed AE. Surrogate markers of disease activity in patients with Takayasu arteritis. A preliminary report from The International Network for the Study of the Systemic Vasculitides (INSSYS). Int J Cardiol. (1998) 66(Suppl. 1):S191-4. doi: 10.1016/S0167-5273(98)00181-8

126. Salvarani C, Cantini F, Boiardi L, Hunder GG. Laboratory investigations useful in giant cell arteritis and Takayasu's arteritis. Clin Exp Rheumatol. (2003) 21:S23-8.

127. Maksimowicz-McKinnon K, Bhatt DL, Calabresse LH. Recent advances in vascular inflammation: C-reactive protein and other inflammatory biomarkers. Curr Opin Rheumatol. (2004)16:18-24. doi: 10.1097/00002281-200401000-00005
128. Ozen S, Bakkaloglu A, Dusunsel R, Soylemezoglu O, Ozaltin F, Poyrazoglu H, et al. Childhood vasculitides in Turkey: a nationwide survey. Clin Rheumatol. (2007) 26:196-200. doi: 10.1007/s10067-006-0266-6

129. Dogan S, Piskin O, Solmaz D, Akar S, Gulcu A, Yuksel F, et al. Markers of endothelial damage and repair in Takayasu arteritis: are they associated with disease activity? Rheumatol Int. (2014) 34:1129-38. doi: 10.1007/s00296-013-2937-3

130. Sun Y, Ma L, Yan F, Liu H, Ding Y, Hou J, et al. MMP-9 and IL-6 are potential biomarkers for disease activity in Takayasu's arteritis. Int J Cardiol. (2012) 156:236-8. doi: 10.1016/j.ijcard.2012.01.035

131. Tripathy NK, Chandran V, Garg NK, Sinha N, Nityanand S. Soluble endothelial cell adhesion molecules and their relationship to disease activity in Takayasu's arteritis. J Rheumatol. (2008) 35:1842-5.

132. Dagna L, Salvo F, Tiraboschi M, Bozzolo EP, Franchini S, Doglioni C, et al. Pentraxin-3 as a marker of disease activity in Takayasu arteritis. Ann Intern Med. (2011) 155:425-33. doi: 10.7326/0003-4819-155-7-20111004000005

133. Ishihara T, Haraguchi G, Kamiishi T, Tezuka D, Inagaki H, Isobe M. Sensitive assessment of activity of Takayasu's arteritis by pentraxin3, a new biomarker. J Am Coll Cardiol. (2011) 57:1712-3. doi: 10.1016/j.jacc.2010.10.058

134. Pan L, Du J, Li T, Liao H. Platelet-to-lymphocyte ratio and neutrophilto-lymphocyte ratio associated with disease activity in patients with Takayasu's arteritis: a case-control study. BMJ Open (2017) 7:e014451. doi: 10.1136/bmjopen-2016-014451

135. Wang X, Dang A, Lv N, Cheng N, Cheng X. Inflammation is associated with platelet coagulation function rather than enzymatic coagulation function in patients with Takayasu Arteritis. Int Heart J. (2017) 58:589-92. doi: 10.1536/ihj.16-533

136. Akazawa H, Ikeda U, Yamamoto K, Kuroda T, Shimada K. Hypercoagulable state in patients with Takayasu's arteritis. Thromb Haemost. (1996) 75:712-6. doi: 10.1055/s-0038-1650353

137. Katsicas MM, Pompozzi L, Russo R. Arteritis de Takayasu en pediatría. Arch Argent Pediatr. (2012) 110:251-5. doi: 10.5546/aap.2012.251

138. Cantu C, Pineda C, Barinagarrementeria F, Salgado P, Gurza A, Paola de Pablo, et al. Noninvasive cerebrovascular assessment of Takayasu Arteritis. Stroke (2000) 31:2197-202. doi: 10.1161/01.STR.31.9.2197

139. Johnston SL, Lock RJ, Gompels MM. Takayasu arteritis: a review. J Clin Pathol. (2002) 55:481-6. doi: 10.1136/jcp.55.7.481

140. Sharma BK, Jain S, Suri S, Numano F. Diagnostic criteria for Takayasu arteritis. Int J Cardiol. (1996) 54(Suppl.):S141-7. doi: 10.1016/S0167-5273(96)88783-3

141. Arend WP, Michel BA, Bloch DA, Hunder GG, Calabrese LH, Edworthy SM, et al. The American College of Rheumatology 1990 criteria for the classification of Takayasu arteritis. Arthritis Rheum. (1990) 33:1129-34. doi: 10.1002/art.1780330811

142. Ozen S, Pistorio A, Iusan SM, Bakkaloglu A, Herlin T, Brik R, et al. EULAR/PRINTO/PRES criteria for Henoch-Schönlein purpura, childhood polyarteritis nodosa, childhood Wegener granulomatosis and childhood Takayasu arteritis: ankara 2008. Part II: final classification criteria. Ann Rheum Dis. (2010) 69:798-806. doi: 10.1136/ard.2009. 116657

143. Watson L. Brogan P, Pert I, Landes C, Barnes N, Cleary G. Diagnosis and assessment of disease activity in Takayasu Arteritis: a childhood case illustrating the challenge. Case Rep Rheumatol. (2014) 2014:603171. doi: 10.1155/2014/603171

144. Merkel PA, Aydin SZ, Boers M, Cornell C, Direskeneli H, Gebhart D, et al Current status of outcome measure development in vasculitis. J Rheumatol. (2014) 41:593-8. doi: 10.3899/jrheum.131248

145. Quartuccio L, Schiavon F, Zuliani F, Carraro V, Catarsi E, Tavoni AG, et al. Long-term efficacy and improvement of health-related quality of life in patients with Takayasu's arteritis treated with infliximab. Clin Exp Rheumatol. (2012) 30:922-8.

146. Demirkaya E, Ozen S, Pistorio A, Galasso R, Ravelli A, Hasija R. Performance of Birmingham Vasculitis Activity Score and disease extent index in childhood vasculitides. Clin Exp Rheumatol. (2012) 30(1 Suppl. 70):S162-8.

147. Bacon P, Sivakumar R, Danda D, Misra R Vasculitis assessment and Takayasu aorto-arteritis. Ind J Rheumatol. (2012) 7:153-8. doi: 10.1016/j.injr.2012.07.001 
148. Sivakumar MR, Misra RN, Bacon PA. The Indian perspective of Takayasu arteritis and development of a disease extent index (DEI.Tak) to assess Takayasu arteritis. Rheumatology (2005) 44(Suppl. 3):iii6-7.

149. Aydin SZ, Yilmaz N, Akar S, Aksu K, Kamali S, Yucel E, et al. Assessment of disease activity and progression in Takayasu's arteritis with disease extent index-Takayasu. Rheumatology (2010) 49:1889-93. doi: 10.1093/rheumatology/keq171

150. Misra R, Danda D, Rajappa SM, Ghosh A, Gupta R, Mahendranath $\mathrm{KM}$, et al. Development and initial validation of the Indian Takayasu clinical activity score (ITAS2010). Rheumatology (2013) 52:1795-801. doi: 10.1093/rheumatology/ket128

151. Dolezalova P, Price-Kuehne FE, Özen S, Benseler SM, Cabral DA, Anton J, et al. Disease activity assessment in childhood vasculitis: development and preliminary validation of the paediatric vasculitis activity score (PVAS). Ann Rheum Dis. (2013) 72:1628-33. doi: 10.1136/annrheumdis-2012-202111

152. Exley AR, Bacon PA, Luqmani RA, Kitas GD, Carruthers DM, Moots R. Examination of disease severity in systemic vasculitis from the novel perspective of damage using the vasculitis damage index (VDI). $\mathrm{Br} J$ Rheumatol. (1998) 37:57-63. doi: 10.1093/rheumatology/37.1.57

153. Sinha D, Mondal S, Nag A, Ghosh A. Development of a colour Dopple ultrasound scoring system in patients of Takayasu's arteritis and its correlation with clinical activity score (ITAS 2010). Rheumatology (2013) 52:2196-202. doi: 10.1093/rheumatology/ket289

154. Nakagomi D, Cousins C, Sznajd J, Furuta S, Mohammad AJ, Luqmani R, et al. Development of a score for assessment of radiologic damage in large-vessel vasculitis (Combined Arteritis Damage Score, CARDS). Clin Exp Rheumatol. (2017) 35(Suppl. 103):S139-45.

155. Mukhtyar C, Guillevin L, Cid MC, Dasgupta B, de Groot K, Gross W, et al, for the European Vasculitis Study Group. EULAR recommendations for the management of large vessel vasculitis. Ann Rheum Dis. (2009) 68:318-23. doi: $10.1136 /$ ard.2008.088351

156. De Graeff N, Groot S, Kamphuis S, Avcin T, Bader-Meunier B, Dolezalova $\mathrm{P}$, et al. Final evidence-based recommendations for diagnosis and treatment of paediatric vasculitides. Ann Rheum Dis. (2015) 74(Suppl. 2):522-3. doi: 10.1136/annrheumdis-2015-eular.6334

157. Hoffman GS, Leavitt RY, Kerr GS Rottem M, Sneller MC, Fauci AS. Treatment of glucocorticoid-resistant or relapsing Takayasu arteritis with methotrexate. Arthritis Rheum. (1994) 37:578-82. doi: 10.1002/art.1780370420

158. Ozen S, Duzova A, Bakkaloglu A, Bilginer Y, Cil BE, Demircin $\mathrm{M}$, et al. Takayasu arteritis in children: preliminary experience with cyclophosphamide induction and corticosteroids followed by methotrexate. J Pediatr. (2007) 150:72-6. doi: 10.1016/j.jpeds.2006.10.059

159. Batu ED, Sönmez HE, Hazirolan T, Özaltin F, Bilginer Y, Özen S. Tocilizumab treatment in childhood Takayasu arteritis: case series of four patients and systematic review of the literatura. Semin Arthritis Rheum. (2017) 46:529-35. doi: 10.1016/j.semarthrit.2016.07.012

160. Nakaoka Y, Isobe M, Takei S, Tanaka Y, Ishii T, Yokota S, et al. Efficacy and safety of tocilizumab in patients with refractory Takayasu arteritis: results from a randomised, double-blind, placebo-controlled, phase 3 trial in Japan (the TAKT study). Ann Rheum Dis. (2018) 77:348-54. doi: 10.1136/annrheumdis-2017-211878

161. Ogino H, Matsuda H, Minatoya K, Sasaki H, Tanaka H, Matsumura $\mathrm{Y}$, et al. Overview of late outcome of medical and surgical treatment for Takayasu arteritis. Circulation (2008) 118:2738-47. doi: 10.1161/CIRCULATIONAHA.107.759589

162. Dai D, Wang YY, Jin H, Mao Y, Sun H. The efficacy of mycophenolate mofetil in treating Takayasu arteritis: a systematic review and meta-analysis. Rheumatol Int. (2017) 37:1083-8. doi: 10.1007/s00296-017-3704-7

163. de Souza AW, da Silva MD, Machado LS, Oliveira AC, Pinheiro FA, Sato EI. Short-term effect of leflunomide in patients with Takayasu arteritis: an observational study. Scand J Rheumatol. (2012) 41:227-30. doi: 10.3109/03009742.2011.633553

164. Shinjo SK, Pereira RM, Tizziani VA, Radu AS, Levy-Neto M. Mycophenolate mofetil reduces disease activity and steroid dosage in Takayasu arteritis. Clin Rheumatol. (2007) 26:1871-5. doi: 10.1007/s10067-007-0596-Z

165. Goel R, Danda D, Mathew J, Edwin N. Mycophenolate mofetil in Takayasu's arteritis. Clin Rheumatol. (2010) 29:329-32. doi: 10.1007/s10067-009-1333-6
166. Daina E, Schieppati A, Remuzzi G. Mycophenolate mofetil for the treatment of Takayasu arteritis: report of three cases. Ann Intern Med. (1999) 130:422-6. doi: 10.7326/0003-4819-130-5-19990302000013

167. Valsakumar AK, Valappil UC, Jorapur V, Garg N, Nityanand S, Sinha N. Role of immunosuppressive therapy on clinical, immunological, and angiographic outcome in active Takayasu's arteritis. J Rheumatol. (2003) 30:1793-8.

168. Hoffman GS, Merkel PA, Brasington RD, Lenschow DJ, Liang P. Anti-tumor necrosis factor therapy in patients with difficult to treat Takayasu arteritis. Arthritis Rheum. (2004) 50:2296-304. doi: 10.1002/art.20300

169. Molloy ES, Langford CA, Clark TM, Gota CE, Hoffman GS, Antitumour necrosis factor therapy in patients with refractory Takayasu arteritis: long-term follow-up. Ann Rheum Dis. (2008) 67:1567-9. doi: 10.1136/ard.2008.093260

170. Filocamo G, Buoncompagni A, Viola S, Loy A, Malattia C, Ravelli A, et al. Treatment of Takayasu's arteritis with tumor necrosis factor antagonists. J Pediatr. (2008) 153:432-4. doi: 10.1016/j.jpeds.2008.04.049

171. Stern S, Silva GC, Reiff A, Ramos M, Marzan K, Terreri MT. Infliximab vs cyclosphosphamide in pediatric Takayasu's arteritis. Ann Rheum Dis. (2012) 71:433.

172. Bravo Manche-o B, Perin F, Guez Vazquez del Rey MM, García SA, Alcázar RPP. Successful tocilizumab treatment in a child with refractory Takayasu arteritis. Pediatrics (2012) 130:e1720-4. doi: 10.1542/peds.2012-1384

173. Osman M, Pagnoux C, Dryden DM, Storie D, Yacyshyn E. The Role of biological agents in the Management of Large Vessel Vasculitis (LVV): a systematic review and meta-analysis. PLoS ONE (2014) 9:e115026. doi: 10.1371 /journal.pone. 0115026

174. Gudbrandsson B, Øyvind Molberg O, Palm O. TNF inhibitors appear to inhibit disease progression and improve outcome in Takayasu arteritis; an observational, population-based time trend study. Arthritis Res Ther. (2017) 19:99. doi: 10.1186/s13075-017-1316-y

175. Mekinian A, Comarmond C, Resche-Rigon M, Mirault T, Kahn JE, Lambert $M$, et al. Efficacy of biological-targeted treatments in Takayasu Arteritis. Multicenter, retrospective study of 49 patients. Circulation (2015) 132:1693-700. doi: 10.1161/CIRCULATIONAHA.114. 014321

176. Goel R, Danda D, Kumar S, Joseph G. Rapid control of disease activity by Tocilizumab in 10 difficult to treat' cases of Takayasu arteritis. Int J Rheum Dis. (2013) 16:754-61. doi: 10.1111/1756-185X.12220

177. Nishimoto N, Nakahara H, Yoshio-Hoshino N, Mima T. Successful treatment of a patient with Takayasu's arteritis using a humanized antiinterleukin 6 receptor antibody. Arthritis Rheum. (2008) 58:1197-200. doi: 10.1002/art.23373

178. Unizony S, Arias-Urdaneta L, Miloslavsky E, Arvikar S, Khosroshahi A, Keroack B, et al. Tocilizumab for the treatment of large-vessel vasculitis (giant cell arteritis, Takayasu arteritis) and polymyalgia rheumatica. Arthritis Care Res. (2012) 64:1720-9. doi: 10.1002/acr.21750

179. Salvarani C, Magnani L, Catanoso M, Pipitone N, Versari A, Dardani L, et al. Tocilizumab: a novel therapy for patients with large-vessel vasculitis. Rheumatology (2012) 51:151-6. doi: 10.1093/rheumatology/ ker296

180. Nakaoka Y, Higuchi K, Arita Y, Otsuki M, Yamamoto K, Hashimoto-Kataoka $\mathrm{T}$, et al. Tocilizumab for the treatment of patients with refractory takayasu arteritis. Int Heart J. (2013) 54:405-11. doi: 10.1536/ihj.54.405

181. Tombetti E, Franchini S, Papa M, Sabbadini MG, Baldissera E. Treatment of refractory takayasu arteritis with tocilizumab: 7 Italian patients from a single referral center. J Rheumatol. (2013) 40:2047-51. doi: 10.3899/jrheum.130536

182. Zhou J, Chen Z, Li J, Yang Y, Zhao J, Chen H, et al. The efficacy of tocilizumab for the treatment of Chinese Takayasu's arteritis. Clin Exp Rheumatol. (2017) 35(Suppl. 103):171-5.

183. Langford CA, Cuthbertson D, Ytterberg SR, Khalidi N, Monach PA, Carette $\mathrm{S}$, et al. A randomized, double-blind trial of abatacept (CTLA-4Ig) for the treatment of Takayasu arteritis. Arthritis Rheumatol. (2017) 69:846-53. doi: 10.1002/art.40037

184. de Souza AWS, Machado MP, Pereira VM, Arraes AE, Reis Neto ET, Mariz HA, et al. Antiplatelet therapy for the prevention of arterial ischemic events in Takayasu Arteritis. Circ J. (2010) 74:1236-41. doi: 10.1253/circj.CJ-09-0905 
185. Maksimowicz-McKinnon K, Clark TM, Hoffman GS. Limitations of therapy and a guarded prognosis in an american cohort of Takayasu Arteritis patients. Arthritis Rheum. (2007) 56:1000-9. doi: 10.1002/art.22404

186. Fields CE, Bower TC, Cooper LT, Hoskin T, Noel AA, Panneton JM, et al. Takayasu's arteritis: operative results and influence of disease activity. J Vasc Surg. (2006) 43:64-71. doi: 10.1016/j.jvs.2005.10.010

187. Saadoun D, Lambert M, Mirault T, Resche-Rigon M, Koskas F, Cluzel P, et al. Retrospective analysis of surgery versus endovascular intervention in Takayasu arteritis: a multicenter experience. Circulation (2012) 125:813-9. doi: 10.1161/CIRCULATIONAHA.111.058032

188. Min PK, Park S, Jung JH, Ko YG, Choi D, Jang Y, et al. Endovascular therapy combined with immunosuppressive treatment for occlusive arterial disease in patients with Takayasu's arteritis. J Endovasc Ther. (2005) 12:28-34. doi: 10.1583/12-01-04-1329.1

189. Park MC, Lee SW, Park YB Lee SK, Choi D, Shim WH. Post-interventional immunosuppressive treatment and vascular restenosis in Takayasu's arteritis. Rheumatology (2006) 45:600-5. doi: 10.1093/rheumatology/kei245

190. Liang $P$ and Hoffman GS. Advances in the medical and surgical treatment of Takayasu arteritis. Curr Op Rheumatol. (2005) 17:16-24. doi: 10.1097/01.bor.0000146607.65808.37

191. Kalangos A, Christenson JT, Cikirikcioglu M, Vala D, Buerge A, Simonet $\mathrm{F}$, et al. Long-term outcome after surgical intervention and interventional procedures for the management of Takayasu's arteritis in children. J Thorac Cardiovasc Surg. (2006) 132:656-64. doi: 10.1016/j.jtcvs.2006.04.020

192. Ladapo TA, Gajjar P, McCulloch M, Scott C, Numanoglu A, Nourse P. Impact of revascularization on hypertension in children with Takayasu's arteritisinduced renal artery stenosis: a 21-year review. Pediatr Nephrol. (2015) 30:1289-95. doi: 10.1007/s00467-015-3049-y
193. Koneti RN, Mahajan N, Bakhru S, Verma S, Kathare P. Emergency renal artery stenting in acute anuric renal failure in children with Takayasu's arteritis. Indian Heart J. (2013) 65:600-2. doi: 10.1016/j.ihj.2013. 08.018

194. Weaver FA, Kumar SR, Yellin AE, Anderson S, Hood DB, Rowe $\mathrm{VL}$, et al. Renal revascularization in Takayasu arteritis-induced renal artery stenosis. J Vasc Surg. (2004) 39:749-57. doi: 10.1016/j.jvs.2003. 12.022

195. Zhu G, He F, Gu Y, Yu H, Chen B, Hu Z, et al. Angioplasty for pediatric renovascular hypertension: a 13-year experience. Diagn Interv Radiol. (2014) 20:285-92. doi: 10.5152/dir.2014.13208

196. Kwon HW, Suh YJ, Bang JS, Kwon BS, Kim GB, Bae EJ, et al. Aortic valve replacement surgery for a case of infantile Takayasu arteritis Korean J Pediatr. (2012) 55:254-8. doi: 10.3345/kjp.2012. 55.7.254

197. Isobe M. Takayasu arteritis revisited: current diagnosis and treatment. Int J Cardiol. (2013) 168:3-10. doi: 10.1016/j.ijcard.2013.01.022

Conflict of Interest Statement: The authors declare that the research was conducted in the absence of any commercial or financial relationships that could be construed as a potential conflict of interest.

Copyright (c) 2018 Russo and Katsicas. This is an open-access article distributed under the terms of the Creative Commons Attribution License (CC BY). The use, distribution or reproduction in other forums is permitted, provided the original author(s) and the copyright owner(s) are credited and that the original publication in this journal is cited, in accordance with accepted academic practice. No use, distribution or reproduction is permitted which does not comply with these terms. 